\title{
Synergistic effects of UVR and simulated stratification on commensalistic phytoplankton-bacteria relationship in two optically contrasting oligotrophic Mediterranean lakes
}

\author{
P. Carrillo ${ }^{1}$, J. M. Medina-Sánchez ${ }^{2}$, C. Durán ${ }^{1}$, G. Herrera ${ }^{1}$, V. E. Villafañe ${ }^{3}$, and E. W. Helbling ${ }^{3}$ \\ ${ }^{1}$ Instituto Universitario de Investigación del Agua, Universidad de Granada, Granada, Spain \\ ${ }^{2}$ Departamento de Ecología, Facultad de Ciencias, Universidad de Granada, Granada, Spain \\ ${ }^{3}$ Estación de Fotobiología Playa Unión and Consejo Nacional de Investigaciones Científicas y Técnicas (CONICET) \\ - Casilla de Correos No 15 (9103) Rawson, Chubut, Argentina
}

Correspondence to: P. Carrillo (pcl@ugr.es)

Received: 21 July 2014 - Published in Biogeosciences Discuss.: 25 August 2014

Revised: 4 December 2014 - Accepted: 26 December 2014 - Published: 4 February 2015

\begin{abstract}
An indirect effect of global warming is a reduction in the depth of the upper mixed layer (UML) causing organisms to be exposed to higher levels of ultraviolet (UVR, $280-400 \mathrm{~nm}$ ) and photosynthetically active radiation (PAR, $400-700 \mathrm{~nm}$ ). This can affect primary and bacterial production as well as the commensalistic phytoplankton-bacteria relationship. The combined effects of UVR and reduction in the depth of the UML were assessed on variables related to the metabolism of phytoplankton and bacteria, during in situ experiments performed with natural pico- and nanoplankton communities from two oligotrophic lakes with contrasting UVR transparency (high-UVR versus low-UVR waters) of southern Spain. The negative UVR effects on epilimnetic primary production (PP) and on heterotrophic bacterial production (HBP), intensified under increased stratification, were higher in the low-UVR than in the high-UVR lake, and stronger on the phytoplanktonic than on the heterotrophic bacterial communities. Under UVR and increased stratification, the commensalistic phytoplankton-bacteria relationship was strengthened in the high-UVR lake where excretion of organic carbon (EOC) rates exceeded the bacterial carbon demand (BCD; i.e., BCD : $\mathrm{EOC}(\%)$ ratio $<100)$. This did not occur in the low-UVR lake (i.e., BCD : $\mathrm{EOC}(\%)$ ratio $>100)$. The greater UVR damage to phytoplankton and bacteria and the weakening of their commensalistic interaction found in the low-UVR lake indicates that these ecosystems would be especially vulnerable to UVR and increased stratification as stressors related to global climate change. Thus, our findings
\end{abstract}

may have important implications for the carbon cycle in oligotrophic lakes of the Mediterranean region.

\section{Introduction}

Rising levels of greenhouse gases (mainly $\mathrm{CO}_{2}$ ), attributed to human activities, have led to an increase of $0.56^{\circ} \mathrm{C}$ in the Earth's surface temperature over the past 150 years (IPCC, 2013). Model predictions indicate greater temperature increases, ranging from 1.5 to $6.4^{\circ} \mathrm{C}$ by the end of the century. Major changes in precipitation have accompanied these temperature variations and are expected to become more pronounced (IPCC, 2013). These climate changes affect aquatic ecosystems by increasing water temperature, altering mixing regimes, shortening the thaw time and the duration of ice cover, and/or strengthening water-column stratification (de Senerpont Domis et al., 2013). These alterations in physical conditions have different effects on primary and bacterial production, plankton growth, nutrient supply, and trophic interactions, among other ecological processes (de Senerpont Domis et al., 2013). In addition, variations in stratification patterns are known to strongly affect biogeochemical cycles (van de Waal et al., 2009).

Higher temperatures in the upper layers of freshwater bodies increase density differences between the upper mixed layer (UML) or epilimnion and deeper waters, augmenting the vertical temperature gradient, and thus the stratification. 
This process has contrasting effects on nutrient and light availability for organisms' growth. On the one hand, stratification reduces the flow of nutrients from deep and nutrientrich areas into the UML, limiting nutrient availability for growth (Huisman et al., 2006). On the other hand, stratification traps phytoplankton populations in surface layers, increasing the light available for growth, but also exposing them to higher levels of ultraviolet radiation (UVR, 280$400 \mathrm{~nm}$ ). In this regard, it has been widely reported that greater exposure to UVR exerts an inhibitory effect on autotrophic and heterotrophic organisms (Häder et al., 2011), and that UV-B $(280-315 \mathrm{~nm})$, in particular, harms primary and bacterial production (Carrillo et al., 2002), enzymatic activity (Korbee et al., 2012), and cell viability (Helbling et al., 1995), among other effects. However, it has been also reported (Aas et al., 1996; Medina-Sánchez et al., 2002; Gao et al., 2007) that UVR does not produce negative effects and it can even stimulate bacterial production and photosynthetic activity. These opposite effects may be attributable to the high acclimation capacity of organisms in high-UVR ecosystems (Medina-Sánchez et al., 2002; Ruiz-González et al., 2013) or to differences in physical-chemical factors (e.g., temperature or nutrient content) among ecosystems (Harrison and Smith, 2009).

With respect to physical factors, it has been experimentally demonstrated (Helbling et al., 1994) that vertical mixing can alter UVR-induced effects on planktonic organisms by generating a regime of fluctuating irradiance, with high values near the surface and low values at the bottom of the UML. The depth of the UML also influences the mean UVR and PAR irradiance received by organisms and the duration of their residence in the photoactive zone (Neale et al., 2003). Studies on the interactive effects of UVR and vertical mixing on phytoplankton (Helbling et al., 1995; Neale et al., 2003) and bacteria (Bertoni et al., 2011) have shown that these organisms can recover from UVR-induced damage when UVR exposure is subsequently reduced or avoided. The outcome of damage vs. repair depends not only on the amount of damaging UVR received but also on photorepair wavelengths (UV-A, PAR) to which organisms are subsequently exposed during the fluctuating radiation regime. Moreover, the effects of different mixing depths, and thus of different mean irradiances, can act synergistically or antagonistically with UVR, depending on the composition, structure, and size of the species, as well as on the environmental conditions (Villafañe et al., 2007). For instance, Barbieri et al. (2002) found that the impact of UVR in Patagonian coastal waters was negative or positive depending on the fraction of the euphotic zone $\left(Z_{\mathrm{eu}}\right)$ that was mixed; thus, UVR was used for photosynthesis when vertical mixing reached $\sim 90 \%$ of the $Z_{\mathrm{eu}}$, but carbon fixation was reduced by UVR when the UML was shallow ( $\sim 60 \%$ of the $Z_{\mathrm{eu}}$ ).

Besides increased stratification of the water column, more extreme rainfall events and storms are predicted in many parts of the Earth in the global-change scenario (IPCC,
2013). This would increase the amount of allochthonous dissolved organic matter (DOM) reaching inland and coastal aquatic ecosystems, reducing the penetration of incident UVR (Rose et al., 2009). The UVR filtering characteristics of colored DOM (CDOM) result in a more effective attenuation of shorter (UV-B) than longer (UV-A, 315-400 nm) wavelengths, as also observed for stratospheric ozone. Concomitantly, the photochemical reactions mediated by UVR lead to (i) the photodegradation of DOM, altering the composition and absorbance of CDOM, and (ii) the photooxidation of DOM, producing oxygen free-radicals (Kitidis et al., 2014). These changes would modulate the response of aquatic organisms to UVR (Williamson and Rose, 2010), making it more complex to predict the interactive effects of UVR and stratification on the planktonic community.

Recent experiments carried out by our group have demonstrated that fluctuating irradiance increases the harmful UVR effects on primary producers in oligotrophic mountain lakes with high DOM, whereas the opposite effects were detected in those with low DOM content (Helbling et al., 2013). Several authors have highlighted the importance of the quality of the radiation, which can interact with DOM and either increase or decrease the availability of organic carbon for bacteria (Pérez and Sommaruga, 2007). However, despite the key role of phytoplankton and heterotrophic bacteria production as a link between the microbial and grazing food webs, no studies on the interactive effects of radiation quality and increased stratification on the commensalistic phytoplankton-bacteria relationship have been done in ecosystems with high- and low-CDOM contents.

A growing body of literature supports the strong dependence of planktonic heterotrophic prokaryotes on organic matter released in situ by phytoplankton in the upper layers of aquatic ecosystems (Baines and Pace, 1991; Norrman et al., 1995; Morán and Alonso-Sáez, 2011). It has also been demonstrated that UVR exposure in the upper layers of the water column can increase the proportion of photosynthate released as exudates (Carrillo et al., 2008; Korbee al., 2012), which would stimulate the growth of UVR-resistant bacteria (Xenopoulos and Schindler, 2003) and give rise to a coupled phytoplankton-bacteria relationship in clear oligotrophic lakes (Carrillo et al., 2002). Coupling between phytoplankton and bacterioplankton has been defined as the capacity of the carbon (C) released by phytoplankton to support the bacterial carbon requirement (Morán et al., 2002) and will therefore differ depending on (i) the availability of alternative (allochthonous or autochthonous) carbon sources (Gasol et al., 2009) and (ii) the supply of inorganic nutrients (Medina-Sánchez et al., 2010; 2013; López-Sandoval et al., 2011). Although the bacterial dependence on $C$ released by phytoplankton is a well-established paradigm in aquatic microbiology (Cole et al., 1988), it is currently under renewed debate. Thus, Fouilland and Mostajir $(2010,2011)$ proposed that $\mathrm{C}$ dependency of bacteria on phytoplankton is uncertain because $\mathrm{C}$ sources other than those from algal origin 
might support the bacterial growth more significantly. However, Morán and Alonso-Sáez (2011) rebutted this idea due to uncertainty found in the application of different conversion factors to raw data and modeled rates in the Fouilland and Mostajir's calculations.

With this background, the aim of the present study was to improve our understanding about the combined effects of UVR exposure and increased stratification on (i) phytoplanktonic and heterotrophic bacterial production and (ii) the commensalistic relationship between them in lakes with different transparency to UVR. We hypothesized that the interactive effects of UVR and increased stratification will accentuate the harmful UVR effects on primary production (PP) and heterotrophic bacterial production (HBP), thus resulting in a greater $\mathrm{C}$ release by phytoplankton, which will strengthen the commensalistic phytoplankton-bacteria relationship. These effects will be more acute in low-UVR than in high-UVR lakes, because UVR-resistant populations are likely not selected in low-UVR lakes.

To test our hypothesis, we carried out in situ experiments to assess the combined impact of solar radiation (i.e., quality) and simulated stratification on metabolism of phytoplankton and bacteria, and their commensalistic relationship, in two oligotrophic lakes with contrasting transparency to UVR in the Mediterranean region.

\section{Methods}

\subsection{Model ecosystems}

The study was performed during September 2011 in two Spanish oligotrophic lakes: La Caldera in Sierra Nevada National Park $\left(37^{\circ} 03^{\prime} \mathrm{N} ; 3^{\circ} 19^{\prime} \mathrm{W} ; 3050 \mathrm{~m}\right.$ a.s.l.) (Granada) and La Conceja in Ruidera Natural Park $\left(38^{\circ} 55^{\prime} \mathrm{N} ; 2^{\circ} 47^{\prime} \mathrm{W}\right.$; 850 ma.s.l.) (Ciudad Real). La Caldera is a mixed oligotrophic (total phosphorus [TP] $<0.3 \mu \mathrm{M}$ and chlorophyll $a$ $[\mathrm{Chl} a]<5 \mu \mathrm{g} \mathrm{L}^{-1}$ ) high-mountain lake above the treeline on a siliceous bedrock in a glacial cirque (Carrillo et al., 2006). This lake has a surface area of 2 ha and a mean depth of $4.3 \mathrm{~m}$, with a maximum depth interannually varying from 2 to $14 \mathrm{~m}$. UVR of considerable intensity penetrates deeply in the lake due to the high transparency of the water and low values of dissolved organic carbon $([\mathrm{DOC}]<0.08 \mathrm{mM})$ as reported in Carrillo et al. (2008) and Helbling et al. (2013). Therefore, this lake is hereafter called the "high-UVR" lake. The pelagic community is relatively simple (Carrillo et al., 2006) and it is characterized by the scarcity of ciliates and absence of heterotrophic nanoflagellates and autotrophic picoplankton, and no size overlaps exist between phytoplankton and heterotrophic bacteria (Medina-Sánchez et al., 2002). La Conceja is a stratified oligotrophic lake (TP $<0.03 \mu \mathrm{M}$ and Chl $a<5 \mu \mathrm{g} \mathrm{L}^{-1}$ ), although it has an elevated nitrate concentration which can exceed $800 \mu \mathrm{M}$ due to agricultural use of the land. This lake has a surface area of 29 ha and maximum depth of $14 \mathrm{~m}$. The DOC content ranges from 0.15 to $0.25 \mathrm{mM}$. Therefore, this lake is hereafter called the "low-UVR" lake. The autotrophic community is composed of pico- and nanoplankton (Rojo et al., 2012).

\subsection{Experimental setup}

To assess the interactive effects of solar radiation quality ("UVR" factor) and stratification conditions ("STRAT" factor) on PP, HBP, TPR (total planktonic respiration $<45 \mu \mathrm{m}$ fraction), and $\mathrm{BR}$ (bacterial respiration $<1 \mu \mathrm{m}$ fraction in the high-UVR lake alone), samples were collected from the surface $(0-0.5 \mathrm{~m})$ epilimnetic water. An acid-cleaned $6 \mathrm{~L}$ horizontal Van Dorn sampler was used to collect the water that was pre-screened through a $45 \mu \mathrm{m}$ mesh to remove large zooplankton prior to the experiments. Samples for PP were placed in $50 \mathrm{~mL}$ quartz flasks, and those for HBP, TPR, and BR in $25 \mathrm{~mL}$ quartz flasks. In the low-UVR lake, samples for PP, HBP, and TPR analyses were also gathered from the hypolimnetic water below the thermocline at $6 \mathrm{~m}$ depth, where UV-B did not reach the cells. The idea behind sampling these two communities in the low-UVR lake was to compare the responses of phytoplankton and bacterial communities that had different light histories and degree of acclimation to solar radiation when exposed to similar light quality treatments and irradiance conditions. Since this sharp contrast did not occur in the high-UVR lake, only samples from the $0-0.5 \mathrm{~m}$ were used in these experiments.

The experimental design consisted of three (for TPR and $\mathrm{BR}$ ), four (for PP, HBP), or two (for TPR in the low-UVR lake) "UVR" treatments combined with the two stratification conditions. (1) The UVR treatments (triplicates for each condition) were as follows: (i) PAB - full solar radiation, uncovered quartz flasks; (ii) PA - exclusion of UV-B (280$320 \mathrm{~nm}$ ), flasks wrapped with Folex 320 film (Folex, Germany); (iii) P, control - exclusion of UVR (280-400 nm), flasks wrapped with Ultraphan UV Opak395 film (Digrefa, Germany); and (iv) dark - flasks wrapped with black tape. The optical properties of the filters used for the radiation treatments have been published elsewhere (Villafañe et al., 2003); the filters were replaced before each experiment and tested using a double-beam spectrophotometer (PerkinElmer Lambda 40). (2) The stratification treatments were the following: (i) subsurface, samples incubated at $0.5 \mathrm{~m}$ depth; (ii) mixed, samples subjected to vertical mixing from 0 to $5 \mathrm{~m}$ depth. To simulate these reductions in the depth of the UML (i.e., from $5 \mathrm{~m}$ to near the surface), two round trays containing the samples were exposed in situ to solar radiation. One tray was placed at $0.5 \mathrm{~m}$ depth (subsurface) subjected to irradiance oscillations associated with waves at the surface. This treatment represents the worst-case scenario in terms of solar radiation (i.e., high summer irradiance conditions), in combination with a sharp increase of thermal stratification (i.e., simulating the formation of near-surface thermoclines) during the usually warm Mediterranean summer. Transient 
thermoclines trapping phytoplankton very close to the surface have previously been detected in aquatic environments (Neale et al., 2003). The second tray was vertically moved between the surface and $5 \mathrm{~m}$ depth to simulate the irradiance changes in the upper $5 \mathrm{~m}$ of the water column (mixed). The speed of movement was $1 \mathrm{~m}$ every $2 \mathrm{~min}$, achieved by a custom-made mixing simulator, using a frequency-controlled DC motor (Maxon motor, Switzerland) to impose a linear transport rate on the vessels from the surface to the mixing depth and back. The tray was placed on a boat anchored in a deep area of each lake in such a manner as to avoid shadows or any type of interference from the shoreline or boat. All incubations lasted for $3.5 \mathrm{~h}$ centered on local noon, and a total of 10 cycles (from the surface to $5 \mathrm{~m}$ depth to the surface again) were completed for the mixed condition.

Unfortunately, space restrictions within the trays prevented the performance of all experimental treatments in the low-UVR lake for TPR, which was measured only in samples exposed to $\mathrm{PAB}$ and $\mathrm{P}$ in the subsurface and mixed treatments. The overlapping between autotrophic and heterotrophic picoplankton precluded the measurements of BR in the low-UVR lake.

\subsection{Physical measurements}

Incident solar radiation was continuously monitored by means of a BIC radiometer (deck unit, Biospherical Instruments Inc., CA, USA) that has three channels in the UVR region of the spectrum $(305,320$, and $380 \mathrm{~nm})$ and one broadband channel for PAR $(400-700 \mathrm{~nm})$. Vertical profiles of solar radiation in the water column were performed at noon using a BIC radiometer (underwater unit) with temperature and depth sensors, in addition to the aforementioned channels. Vertical profiles of temperature and $\mathrm{pH}$ in the water column were measured using a multiparameter probe (Turo Water Quality Analysis T-611 Sandy Bay, Tasmania, Australia). These profiles were done daily at noon, and the temperature data were used to estimate the strength and depth of the epilimnion.

\subsection{Chemical analyses}

Samples for chemical and biological variables were collected with a $6 \mathrm{~L}$ Van Dorn sampler at the deepest central station at four depths in the high-UVR lake (surface, 5, 8, and 10 m) and six in the low-UVR lake (surface, 2, 4, 6, 8, and $10 \mathrm{~m}$ ). Water samples were taken to determine the bacterial abundance (BA, $20 \mathrm{~mL}$ ), phytoplankton species composition and abundance $(250 \mathrm{~mL})$, and Chl $a(1 \mathrm{~L})$. Samples were also collected for the chemical determination of total nitrogen (TN), TP, total dissolved nitrogen (TDN), total dissolved phosphorus (TDP), nitrate $\left(\mathrm{NO}_{3}^{-}\right)$, and soluble reactive phosphorus (SRP). The samples for TDN, TDP, $\mathrm{NO}_{3}^{-}$, and SRP analyses were filtered through GF/F Whatman filters $(47 \mathrm{~mm}$ in diameter) before the determinations. Samples for TP and
TDP were persulfate-digested at $120^{\circ} \mathrm{C}$ for $30 \mathrm{~min}$ and determined (as for SRP) using $10 \mathrm{~cm}$ quartz cuvettes (following the acid molybdate technique; APHA, 1992). TN and TDN samples were also persulfate-digested and measured as $\mathrm{NO}_{3}^{-}$by means of the ultraviolet spectrophotometric screening method (APHA, 1992). Blanks and standards were run in all procedures. DOC values were determined by filtering the samples through pre-combusted $\left(2 \mathrm{~h}\right.$ at $\left.500{ }^{\circ} \mathrm{C}\right)$ glass fiber filters (Whatman GF/F) and acidifying them with $\mathrm{HCl}$. Samples were then measured in a total organic carbon analyzer (TOC-VCSH/CSN Shimadzu).

\subsection{Analysis biological variables}

Chl a concentration: For measurements of the Chl $a$ concentration, water samples collected from different depths in the water column were filtered onto Whatman GF/F filters ( $25 \mathrm{~mm}$ in diameter), which were frozen at $-20^{\circ} \mathrm{C}$ until analyses. For Chl $a$ analysis, samples were thawed and placed in centrifuge tubes $(15 \mathrm{~mL})$ with $5 \mathrm{~mL}$ of acetone $(90 \%)$ for $24 \mathrm{~h}$ in the dark at $4{ }^{\circ} \mathrm{C}$. Next, the samples were centrifuged, and the fluorescence of the supernatant was measured with a fluorometer (LS 55 Perkin Elmer, USA) (APHA, 1992).

Identification and cell counting: Samples for the identification and counting of phytoplankton were placed in $250 \mathrm{~mL}$ brown glass bottles and fixed with Lugol's reagent (approx. $1 \% v / v)$. Sub-samples $(100 \mathrm{~mL})$ were settled for $48 \mathrm{~h}$ in Utermöhl chambers (Hydro-Bios $\mathrm{GmbH}$ ), and species were then identified and counted using an inverted microscope (Leitz Fluovert FS, Leica, Wetzlar, Germany). Phytoplankton biovolumes were estimated from measurements of 20-30 cells of each species using image analysis (inverted microscope Axio Observer A1, Zeiss; highresolution microscopy camera Axiocam HRc, Zeiss). Cell volume was calculated according to Carrillo et al. (1995), and converted to phytoplankton carbon using the conversion factors reported by Rocha and Duncan (1985). Bacterial abundance (BA) was determined by the 4',6-diamidino2-phenylindole (DAPI) direct-count method described by Porter and Feig (1980). Water samples were fixed with neutralized formaldehyde $(2 \%)$, stained with DAPI to a final concentration of $2.5 \mu \mathrm{g} \mathrm{mL} \mathrm{m}^{-1}$, and then filtered onto $0.2 \mu \mathrm{m}$ pore-size polycarbonate black filter. At least 400 cells per sample were counted by means of epifluorescence microscopy (Carl Zeiss AX10). Bacterial biomass (BB) was estimated from bacterial biovolume, measured from bacterial images obtained by transmission electron microscopy (TEM) as described by Medina-Sánchez et al. (1999).

\subsection{Analysis of biotic functional variables}

Primary production and excreted organic carbon: For PP measurements, samples of phytoplankton communities were placed in $50 \mathrm{~mL}$ round quartz flasks (three clear and one dark per radiation treatment), inoculated with $0.37 \mathrm{MBq}$ of 
$\mathrm{NaH}^{14} \mathrm{CO}_{3}$ (specific activity: $310.8 \mathrm{MBq} \mathrm{mmol}^{-1}$; DHI Water and Environment, Germany), and exposed to solar radiation in situ, as described above. The total organic carbon (TOC) produced was measured on $4 \mathrm{~mL}$ aliquots before filtration. The samples for PP were filtered onto $0.2 \mu \mathrm{m}$ filters ( $25 \mathrm{~mm}$ diameter, Nuclepore, Whatman) under low vacuum $(<100 \mathrm{~mm} \mathrm{Hg})$ to minimize cell breakage. Excretion of organic carbon (EOC) was measured on $4 \mathrm{~mL}$ aliquots from the filtrates $(<0.2 \mu \mathrm{m})$. Both filters and filtrates were placed in $20 \mathrm{~mL}$ scintillation vials and acidified with $100 \mu \mathrm{L}$ of $1 \mathrm{~N}$ $\mathrm{HCl}$ for $24 \mathrm{~h}$ (no bubbling) to remove inorganic ${ }^{14} \mathrm{C}$ before the addition of liquid scintillation cocktail (Ecoscint A) to the vials. The amount of organic carbon produced was obtained by counting disintegrations per minute (dpm), using an autocalibrated scintillation counter (Beckman LS $6000 \mathrm{TA}$ ). The total $\mathrm{CO}_{2}$ in the lake water was calculated from alkalinity and pH measurements (APHA, 1992). In all calculations, dark values were subtracted from the corresponding light values (more details in Carrillo et al., 2002). The \%EOC was estimated as

$\% \mathrm{EOC}=100 \times(\mathrm{EOC} / \mathrm{TOC})$.

Heterotrophic bacterial production: Samples for HBP measurements were placed in $25 \mathrm{~mL}$ quartz flasks and exposed in situ for $3.5 \mathrm{~h}$ under the radiation and stratification conditions as described above. Then, the HBP was determined as incorporation of ${ }^{3} \mathrm{H}$-thymidine (specific activity $=52 \mathrm{Ci} \mathrm{mmol}^{-1}$, Amersham Pharmacia) into the bacterial DNA, in darkness. Briefly, ${ }^{3} \mathrm{H}$-thymidine was added to independent sets of five (three replicates plus two blanks per treatment) sterile microcentrifuge tubes filled with $1.5 \mathrm{~mL}$ of the pre-exposed samples to a final (saturating) concentration of $15.2 \mathrm{nM}$. The vials were then incubated at in situ temperature in darkness for $1 \mathrm{~h}$. After incubation, the incorporation of ${ }^{3} \mathrm{H}$-thymidine was stopped by adding trichloroacetic acid (TCA, $6 \%$ final concentration). Likewise, blanks were TCA-killed before the radiotracer was added. After the cold TCA extraction, the precipitate was collected by centrifugation at $14000 \mathrm{rpm}$ for $10 \mathrm{~min}$. The conversion factor $1.5 \times 10^{18} \mathrm{cell} \mathrm{mol}^{-1}$ was used to estimate the number of bacteria produced per mole of incorporated ${ }^{3} \mathrm{H}$-thymidine (Bell, 1993). The factor $20 \mathrm{fg} \mathrm{C} \mathrm{Cell}^{-1}$ was applied to convert bacterial production into C (Lee and Fuhrman, 1987).

Respiration rates: Samples for TPR $(<45 \mu \mathrm{m}$ fraction) and $\mathrm{BR}(<1 \mu \mathrm{m}$ fraction) measurements were placed in $25 \mathrm{~mL}$ quartz flasks and exposed in situ for $3.5 \mathrm{~h}$ under the radiation and stratification conditions described above. TPR and BR rates were measured in darkness using optode sensor spots (SP-PSt3-NAU-D5-YOP; PreSens GmbH, Germany) and an optic-fiber oxygen transmitter (Fibox 3; PreSens GmbH, Germany) connected to a computer. Data were recorded using OxyView 3.51 software (PreSens GmbH). The system was calibrated by a two-point calibration, together with data of atmospheric pressure and temperature, before each experiment, following the manufacturer's recommendations. Measurements were made at the initial time $\left(t_{0}\right)$ and then every hour over $8 \mathrm{~h}$. Every oxygen measurement was done over $30 \mathrm{~s}$ with a frequency of 1 datum s$^{-1}$; only the last 10 data points of each measurement were used in our analysis to ensure the stability of the data. Oxygen data were then adjusted to a linear model via least-squares regression. Slope of the regressions provided the oxygen consumption rates $\left(\mu \mathrm{M} \mathrm{O}_{2} \mathrm{~h}^{-1}\right)$ (Warkentin et al., 2007). Oxygen was converted into carbon units using a respiratory quotient of 1 (del Giorgio and Cole, 1998).

The bacterial carbon demand (BCD) is the HBP plus BR. The bacterial growth efficiency (BGE) is the proportion of $\mathrm{C}$ entering the bacterial pool that is incorporated into the biomass, and was calculated as $\mathrm{BGE}=\mathrm{HBP} / \mathrm{BCD}$. The absence of size overlapping between phytoplankton and bacteria in the high-UVR lake (Medina-Sánchez et al., 2002) allowed for a direct measurement of BR. This, however, was not possible in the low-UVR lake, since autotrophic picoplankton and bacteria co-existed in the $<3 \mu \mathrm{m}$ fraction. Therefore, BCD in this lake was estimated by assuming that BR values lie within two limits: (i) a conservative value of $75 \%$ of TPR, which is an average value based on data reported for oligotrophic waters (Lemeé et al., 2002), and (ii) a potential minimum value of $50 \%$ of TPR (Robinson, 2008), comparable with direct measurements made in this study on the TPR vs. BR in La Caldera (Herrera et al., unpublished data).

\subsection{Data calculation and statistical analysis}

The effect size of the UVR was quantified as

$$
\begin{gathered}
\text { Effect size of UV-B }(\%)=100 \times\left[\left(\left(\mathrm{C}_{\mathrm{P}}-\mathrm{C}_{\mathrm{PAB}}\right) / \mathrm{C}_{\mathrm{P}}\right)\right. \\
\left.-\left(\left(\mathrm{C}_{\mathrm{P}}-\mathrm{C}_{\mathrm{PA}}\right) / \mathrm{C}_{\mathrm{P}}\right)\right], \\
\text { Effect size of UV-A }(\%)=100 \times\left[\left(\mathrm{C}_{\mathrm{P}}-\mathrm{C}_{\mathrm{PA}}\right) / \mathrm{C}_{\mathrm{P}}\right],
\end{gathered}
$$

where $\mathrm{C}_{\mathrm{P}}, \mathrm{C}_{\mathrm{PA}}$, and $\mathrm{C}_{\mathrm{PAB}}$ represent the carbon production by phytoplankton or bacteria in samples under the P, PA, and PAB treatments, respectively. We used propagation errors to calculate the variance of the effect size (as percentage) due to UV-B and UV-A. The change $(\Delta)$ in the effect size of UV$B$ and UV-A, between the subsurface and mixed treatments, was calculated as the difference of the effect size for each radiation band.

The effects of solar radiation quality ("UVR" factor) and stratification ("STRAT" factor) on the response variables were tested using two-way ANOVA. When the interactive effects were significant, a post hoc Bonferroni test was used to determine significant differences among treatments. The normality (Kolgomorov-Smirnov test) and homoscedasticity (Cochran-Hartley-Bartlett test) were checked for each data group before ANOVA application. HBP data from the hypolimnetic community in the low-UVR lake were logtransformed to meet ANOVA assumptions. Significance of 
Table 1. Mean values of the main physical, chemical, and biological variables measured in the water column in La Caldera (highUVR lake) and La Conceja (low-UVR lake). Values of vertical attenuation coefficients $\left(k d, \mathrm{~m}^{-1}\right)$ in the $\operatorname{UVR}(305,320,380 \mathrm{~nm})$ and photosynthetically active radiation (PAR, 400-700 nm) regions are shown. Values are mean $( \pm \mathrm{SD})$ of concentrations for four ( $\mathrm{La}$ Caldera) or six (La Conceja) depths of inorganic, total, and dissolved nitrogen $(\mathrm{N})$ and phosphorus $(\mathrm{P})$, chlorophyll $a$, and phytoplankton and bacterial abundances. TN: total nitrogen; TDN: total dissolved nitrogen; $\mathrm{NO}_{3}^{-}$: nitrate; TP: total phosphorus; TDP: total dissolved phosphorus; SRP: soluble reactive phosphorus; Chl $a$ : chlorophyll $a$ concentration; PA: phytoplankton abundance; PB: phytoplankton biomass; BA: bacterial abundance; BB: bacterial biomass.

\begin{tabular}{|c|c|c|}
\hline Variable & High-UVR lake & Low-UVR lake \\
\hline$k d_{305}$ & 0.61 & 4.84 \\
\hline$k d_{320}$ & 0.52 & 2.53 \\
\hline$k d_{380}$ & 0.34 & 0.93 \\
\hline$k d_{\mathrm{PAR}}$ & 0.25 & 0.28 \\
\hline $\mathrm{TN}(\mu \mathrm{M})$ & $21.50 \pm 1.54$ & $787.1 \pm 10.7$ \\
\hline $\operatorname{TDN}(\mu \mathrm{M})$ & $20.71 \pm 1.46$ & $786.4 \pm 12.9$ \\
\hline $\mathrm{NO}_{3}^{-}(\mu \mathrm{M})$ & $14.28 \pm 1.02$ & $702.1 \pm 6.7$ \\
\hline $\mathrm{TP}(\mu \mathrm{M})$ & $0.10 \pm 0.003$ & $0.06 \pm 0.012$ \\
\hline $\mathrm{TDP}(\mu \mathrm{M})$ & $0.051 \pm 0.002$ & $0.038 \pm 0.012$ \\
\hline $\operatorname{SRP}(\mu \mathrm{M})$ & $0.02 \pm 0.001$ & $0.018 \pm 0.012$ \\
\hline Chl $a\left(\mu g \mathrm{~L}^{-1}\right)$ & $2.02 \pm 0.42$ & $2.66 \pm 0.46$ \\
\hline $\mathrm{PA}\left(\right.$ cell $\left.\mathrm{mL}^{-1}\right) \times 10^{3}$ & $7.03 \pm 1.65$ & $4.03 \pm 0.72$ \\
\hline $\mathrm{PB}\left(\mu \mathrm{g} \mathrm{C} \mathrm{L}^{-1}\right)$ & $15.10 \pm 4.31$ & $95 \pm 5.72$ \\
\hline $\mathrm{BA}\left(\right.$ cell $\left.\mathrm{mL}^{-1}\right) \times 10^{6}$ & $1.94 \pm 0.17$ & $1.28 \pm 0.21$ \\
\hline $\mathrm{BB}\left(\mu \mathrm{g} \mathrm{CL}^{-1}\right)$ & $8.66 \pm 1.32$ & $0.98 \pm 0.03$ \\
\hline
\end{tabular}

the effect size of UV-B and UV-A on PP and HBP between subsurface and mixed conditions was evaluated by means of a $t$ test. Regression analyses were done to assess the dependence of the BGE on the EOC rates for the experimental data in each lake. Statistica 7.1 software for Windows was used for the statistical analyses.

\section{Results}

\subsection{Physical, chemical, and biological variables in the water column}

The lakes greatly differed in their transparency to UVR, but not to PAR (Table 1). Thus, in the high-UVR lake, $1 \%$ of the surface energy at $305 \mathrm{~nm}$ reached the bottom of the lake, whereas in the low-UVR lake most of the UVR energy was attenuated in the upper layers (1\% of the surface energy at $305 \mathrm{~nm}$ reached only ca. $1 \mathrm{~m}$ depth). This differential penetration of solar UVR resulted in two contrasting environments, with organisms being exposed to UV-B throughout the water column in the high-UVR lake but only in the upper $1-2 \mathrm{~m}$ of the water column in the low-UVR lake. This was related to the different DOC concentrations in the lakes,
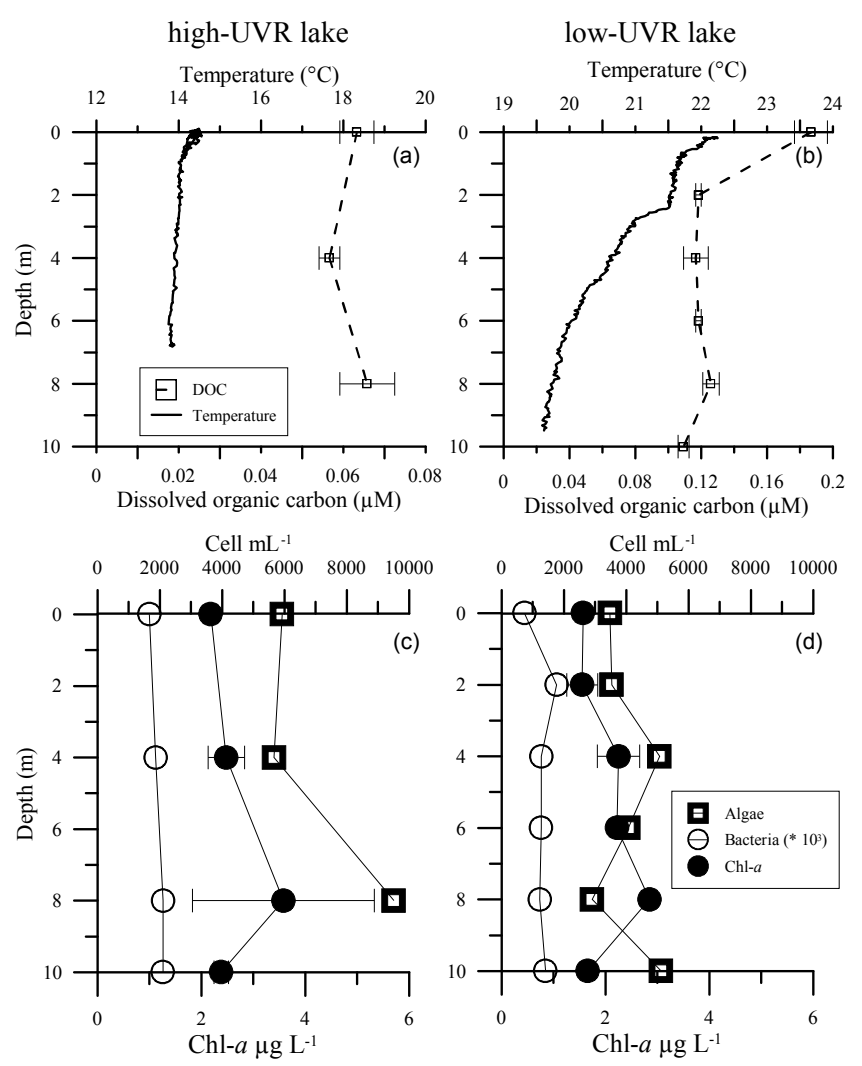

Figure 1. Water column characteristics of the high-UVR lake (a, c) and low-UVR lake (b, d). Depth profiles of temperature $\left({ }^{\circ} \mathrm{C}\right)$ and dissolved organic carbon (DOC in $\mu \mathrm{M})(\mathbf{a}, \mathbf{b})$, as well as phytoplanktonic and bacterial abundances $\left(\right.$ cell $\left.\mathrm{mL}^{-1}\right)$ and chlorophyll $a$ concentration $\left(\mu \mathrm{g} \mathrm{L}^{-1}\right)(\mathbf{c}, \mathbf{d})$. Each symbol represents the mean of triplicate samples, while the horizontal error lines are the standard deviation.

reaching values of 0.07 and $0.18 \mathrm{mM}$ in the high-UVR and low-UVR lakes, respectively (Fig. 1a, b). Vertical temperature profiles also differed between the lakes: the temperature was $14^{\circ} \mathrm{C}$, ranging by only $0.4^{\circ} \mathrm{C}$ between the surface and bottom in the high-UVR lake, whereas a weak thermal stratification between 2 and $3 \mathrm{~m}$ was detected in the low-UVR lake, where the temperature ranged from 22 to $19.5^{\circ} \mathrm{C}$ between the surface and bottom layers (Fig. 1a, b).

The concentrations of total dissolved and inorganic forms of $\mathrm{N}$ and $\mathrm{P}$ were homogeneous in the water column in both lakes; therefore, only mean values are reported in Table 1. TN values were higher in the low-UVR than in the highUVR lake by up to 1 order of magnitude, and $\mathrm{NO}_{3}^{-}$constituted most of the TN $(90 \%$ in the low-UVR and $68 \%$ in the high-UVR lake). By contrast, TP values were $<0.16 \mu \mathrm{M}$ and mostly in organic form in both lakes. The $\mathrm{NO}_{3}^{-}: \mathrm{TP}$ ratio was $>100$ in the high-UVR lake and $>10000$ in the low-UVR lake, indicating a strong $\mathrm{P}$ limitation (Table 1).

Chl $a$ concentrations had small variations with depth in both lakes (Fig. 1c, d). However, the vertical distribution of 
Table 2. Mean irradiances during the incubations for $305 \mathrm{~nm}, 320 \mathrm{~nm}$ and $380 \mathrm{~nm}$ within the UVR wavelengths $\left(\mu \mathrm{W} \mathrm{cm}{ }^{-2} \mathrm{~nm}^{-1}\right)$ and for PAR ( $\mu$ mol photons $\mathrm{m}^{-2} \mathrm{~s}^{-1}$ ). The ratio of the mean irradiances of 380 and $305 \mathrm{~nm}$ is also presented.

\begin{tabular}{llccccc}
\hline Wavelength & & $305 \mathrm{~nm}$ & $320 \mathrm{~nm}$ & $380 \mathrm{~nm}$ & PAR & UV-A $_{380}:$ UV-B \\
\hline \multirow{2}{*}{ High-UVR lake } & Subsurface & 3.90 & 23.40 & 60.10 & 1480 & 15.41 \\
& Mixed & 1.40 & 9.50 & 31.50 & 900 & 22.50 \\
Low-UVR lake & Subsurface & 1.44 & 12.90 & 47.90 & 1428 & 33.26 \\
& Mixed & 0.16 & 1.80 & 12.80 & 824 & 80.00 \\
\hline
\end{tabular}

Table 3. Results of the two-way ANOVA of the interactive effect of "UVR" (PAB, PA, P, dark) and "STRAT" factors on carbon incorporation by phytoplankton ( $\mathrm{PP}, \mu \mathrm{g} \mathrm{CL} \mathrm{L}^{-1} \mathrm{~h}^{-1}$ ), and excreted organic carbon (EOC, $\mu \mathrm{gCL}^{-1} \mathrm{~h}^{-1}$ ), heterotrophic bacterial production (HBP, $\mu \mathrm{gCL}^{-1} \mathrm{~h}^{-1}$ ), bacterial respiration (BR, $\mu \mathrm{gCL}^{-1} \mathrm{~h}^{-1}$; directly measured in the high-UVR lake or calculated as $50 \%$ of total planktonic respiration (TPR) in the low-UVR lake), bacterial growth efficiency (BGE), and ratio of bacterial carbon demand to excretion of organic carbon (BCD : EOC) as a percentage. Numbers in bold indicate $p<0.05$. df1, df2, and df3, df4, are the degrees of freedom.

\begin{tabular}{|c|c|c|c|c|c|c|c|c|c|c|c|c|c|c|c|c|c|c|c|}
\hline & & \multirow[b]{2}{*}{$\mathrm{df}_{1}$} & \multirow[b]{2}{*}{$\mathrm{df}_{2}$} & \multicolumn{2}{|c|}{ PP } & \multicolumn{2}{|c|}{ EOC } & \multirow[b]{2}{*}{$\mathrm{df}_{3}$} & \multirow[b]{2}{*}{$\mathrm{df}_{4}$} & \multicolumn{2}{|c|}{ HBP } & \multirow[b]{2}{*}{$\mathrm{df}_{1}$} & \multirow[b]{2}{*}{$\mathrm{df}_{2}$} & \multicolumn{2}{|c|}{$\mathrm{BR}$} & \multicolumn{2}{|c|}{ BGE } & \multicolumn{2}{|c|}{ BCD : EOC (\%) } \\
\hline & & & & $F_{\mathrm{df1} 1 \mathrm{df} 2}$ & $p$ & $F_{\mathrm{df1} 1 \mathrm{df} 2}$ & $p$ & & & $F_{\mathrm{df3}, \mathrm{df} 4}$ & $p$ & & & $F_{\mathrm{df1}, \mathrm{df} 2}$ & $p$ & $F_{\mathrm{df} 1, \mathrm{df} 2}$ & $p$ & $F_{\mathrm{df1}, \mathrm{df} 2}$ & $p$ \\
\hline \multicolumn{20}{|l|}{ High-UVR lake } \\
\hline \multirow[t]{3}{*}{ Epilimnetic } & STRAT & 1 & 12 & 42.29 & $<0.001$ & 44.00 & $<0.001$ & 1 & 16 & 6.41 & 0.022 & 1 & 12 & 1.07 & 0.321 & 0.26 & 0.619 & 6.15 & 0.029 \\
\hline & UVR & 2 & 12 & 124.12 & $<0.001$ & 6.33 & 0.013 & 3 & 16 & 8.65 & 0.001 & 2 & 12 & 12.38 & 0.001 & 7.22 & 0.009 & 35.47 & $<0.001$ \\
\hline & UVR $\times$ STRAT & 2 & 12 & 20.90 & $<0.001$ & 0.11 & 0.895 & 3 & 16 & 5.46 & 0.009 & 2 & 12 & 3.71 & 0.056 & 4.80 & 0.029 & 14.59 & 0.001 \\
\hline \multicolumn{20}{|l|}{ Low-UVR lake } \\
\hline \multirow[t]{3}{*}{ Epilimnetic } & STRAT & 1 & 12 & 0.61 & 0.450 & 2.46 & 0.143 & 1 & 16 & 7.37 & 0.015 & 1 & 8 & 5.28 & 0.05 & 1.45 & 0.263 & 18.76 & 0.002 \\
\hline & UVR & 2 & 12 & 6.78 & 0.011 & 9.78 & 0.003 & 3 & 16 & 27.96 & $<0.001$ & 1 & 8 & 0.14 & 0.72 & 46.13 & $<0.001$ & 14.42 & 0.005 \\
\hline & UVR $\times$ STRAT & 2 & 12 & 16.71 & $<0.001$ & 16.51 & $<0.001$ & 3 & 16 & 6.38 & 0.005 & 2 & 8 & 0.63 & 0.45 & 0.06 & 0.810 & 44.86 & $<0.001$ \\
\hline \multirow[t]{3}{*}{ Hypolimnetic } & STRAT & 2 & 12 & 0.33 & 0.574 & 4.33 & 0.060 & 1 & 16 & 32.98 & $<0.001$ & 1 & 8 & 0.29 & 0.604 & 6.01 & 0.040 & 4.65 & 0.063 \\
\hline & UVR & 2 & 12 & 41.58 & $<0.001$ & 52.75 & $<0.001$ & 3 & 16 & 12.05 & $<0.001$ & 1 & 8 & 8.39 & 0.020 & 0.15 & 0.711 & 0.81 & 0.394 \\
\hline & UVR $\times$ STRAT & 2 & 12 & 0.39 & 0.688 & 3.21 & 0.076 & 3 & 16 & 7.98 & 0.002 & 2 & 8 & 0.90 & 0.372 & 5.24 & 0.061 & 1.99 & 0.196 \\
\hline
\end{tabular}

phytoplankton and bacteria differed between the lakes: in the high-UVR lake (Fig. 1c) bacterial abundance was rather homogeneous, but phytoplankton abundance was higher at the deepest depth; however, in the low-UVR lake (Fig. 1d) the abundances of bacteria and phytoplankton were rather uniform with depth. Mean phytoplankton and bacterial abundance values were greater in the high-UVR than in the lowUVR lake (Table 1). In terms of taxonomic composition, the Chlorophyceae Monoraphidium sp. represented $>90 \%$ and $\sim 80 \%$ of the total abundance and biomass, respectively, in the high-UVR lake, whereas the Bacillariophyceae $C y$ clotella ocellata was the dominant species in the low-UVR lake ( $>75 \%$ abundance and $95 \%$ biomass).

\subsection{Variations in solar mean irradiance during experiments}

The mean irradiance for the three wavelengths within the UVR and PAR region received by the samples under the experimental conditions are shown in Table 2 . The mean irradiance at 305, 320, and $380 \mathrm{~nm}$ in the high-UVR lake were 2.8, 2.5-, and 1.9-fold higher, respectively, in the subsurface than in the mixed conditions. The ratios between subsurface and mixed treatments in the low-UVR lake were 8.7-, 7.1-, and 3.7-fold higher for the 305, 320, and $380 \mathrm{~nm}$ wavelengths, respectively. The energy ratio at 380 and $305 \mathrm{~nm}$ (i.e., UV$\mathrm{A}_{380}$ : UV-B 305 ratio) had higher values in the low-UVR lake as compared to the high-UVR lake, reflecting the lower penetration of UV-B in the former.

\subsection{Joint effects of UVR and stratification on phytoplanktonic and bacterial metabolism in the high-UVR lake}

The PP values did not show significant differences between subsurface and mixed conditions in the PAB treatment, while samples under the PA and P treatments had significantly higher PP values at the subsurface than under mixed conditions (Fig. 2a). A significant UVR $\times$ STRAT effect was found for PP (Table 3), and according to our hypothesis the subsurface incubations resulted in higher UV-B $(11.5 \%)$ and UV-A $(18.3 \%)$ inhibition as compared to the mixed incubations (Table 4). UVR at the subsurface also significantly increased the rates of EOC, with significantly higher values in samples under the PAB and PA treatments (Fig. 2b). Likewise, the \%EOC was significantly affected by UV-B, increasing to 22 and $21 \%$ in subsurface and in mixed treatments, respectively (graph (1) in Appendix A). Like PP, HBP did not differ between PAB-subsurface and PAB-mixed treatments. However, HBP was significantly lower under PAsubsurface than under PA-mixed treatments (Fig. 2c), resulting in a significant UVR $\times$ STRAT effect (Table 3). By contrast, only the "UVR" factor significantly affected BR (Fig. 2d, Table 3), with the lowest BR value determined in the PAB-subsurface treatment (Fig. 2d). BGE had higher values in the PAB-subsurface treatment as compared to the other radiation treatments under subsurface conditions; other comparisons between paired treatments did not result in 
Table 4. Effect size of UV-B and UV-A on primary production ( $\mathrm{PP}, \mu \mathrm{g} \mathrm{CL}^{-1} \mathrm{~h}^{-1}$ ) and heterotrophic bacterial production (HBP, $\mu \mathrm{gCL} \mathrm{CL}^{-1} \mathrm{~h}^{-1}$ ) in the effect size of UV-B and UV-A, between the subsurface and mixed treatments, was calculated as the difference of the effect size for each radiation band. Numbers in bold indicate $p<0.05$.

\begin{tabular}{|c|c|c|c|c|c|c|c|c|c|}
\hline & & \multicolumn{4}{|c|}{$\mathrm{PP}$} & \multicolumn{4}{|c|}{ HBP } \\
\hline & & $\%$ UV-B & $\Delta \%$ UV-B & $\%$ UV-A & $\Delta \% \mathrm{UV}-\mathrm{A}$ & $\%$ UV-B & $\Delta \%$ UV-B & $\%$ UV-A & $\Delta \% \mathrm{UV}-\mathrm{A}$ \\
\hline $\begin{array}{l}\text { High-UVR lake } \\
\text { Epilimnetic }\end{array}$ & $\begin{array}{l}\text { Subsurface } \\
\text { Mixed }\end{array}$ & $\begin{array}{l}37.3 \pm 2.4 \\
25.7 \pm 5.0\end{array}$ & 11.55 & $\begin{array}{c}25.6 \pm 7.6 \\
7.3 \pm 7.1\end{array}$ & 18.32 & $\begin{array}{l}2.7 \pm 18.3 \\
23.0 \pm 1.5\end{array}$ & -20.3 & $\begin{array}{l}51.9 \pm 26.7 \\
-58.3 \pm 0.2\end{array}$ & 110.2 \\
\hline $\begin{array}{l}\text { Low-UVR lake } \\
\text { Epilimnetic }\end{array}$ & $\begin{array}{l}\text { Subsurface } \\
\text { Mixed }\end{array}$ & $\begin{array}{c}33.7 \pm 4.2 \\
-6.3 \pm 10.9\end{array}$ & 40.00 & $\begin{array}{c}17.4 \pm 13.9 \\
-10.0 \pm 23.5\end{array}$ & 27.41 & $\begin{array}{l}42.9 \pm 6.2 \\
47.1 \pm 2.0\end{array}$ & -4.2 & $\begin{array}{l}30.0 \pm 8.7 \\
28.2 \pm 6.7\end{array}$ & 1.2 \\
\hline Hypolimnetic & $\begin{array}{l}\text { Subsurface } \\
\text { Mixed }\end{array}$ & $\begin{array}{c}27.2 \pm 22.5 \\
27.1 \pm 5.6\end{array}$ & 0.09 & $\begin{array}{l}20.8 \pm 28.9 \\
26.8 \pm 12.8\end{array}$ & -5.98 & $\begin{array}{l}52.1 \pm 5.8 \\
6.5 \pm 12.2\end{array}$ & 45.6 & $\begin{array}{c}12.0 \pm 24.4 \\
23.6 \pm 2.6\end{array}$ & -11.5 \\
\hline
\end{tabular}

Epilimnetic community high-UVR lake
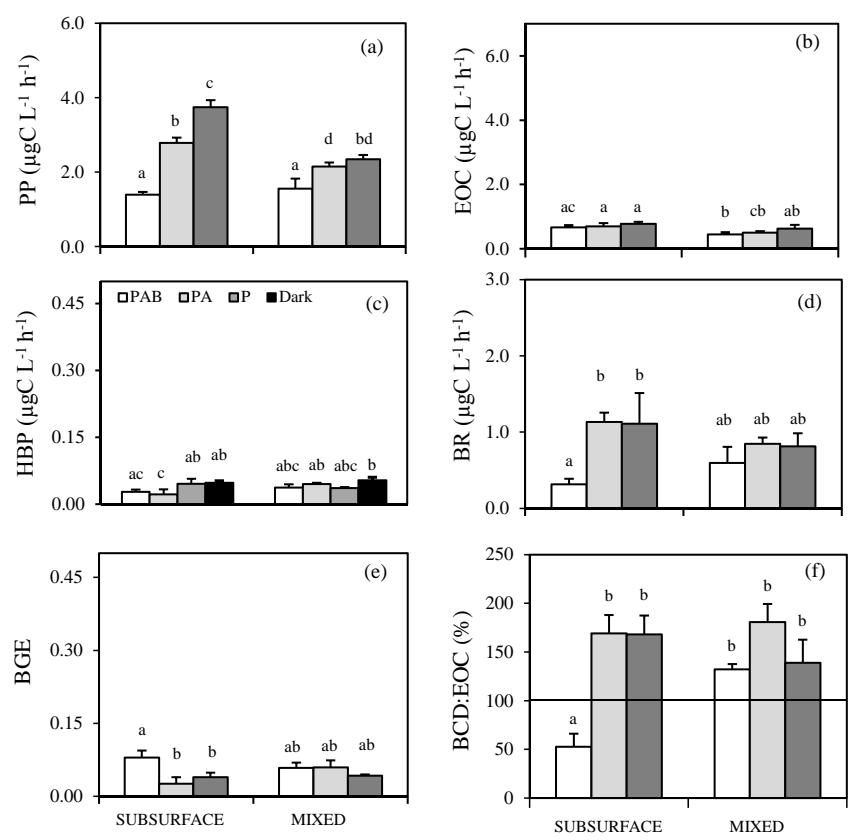

Figure 2. Metabolic variables of epilimnetic community under different radiation treatments (PAB, PA, P, dark) and different stratification conditions (subsurface, mixed) in the high-UVR lake. (a) Primary production (PP, in $\mu \mathrm{g} \mathrm{CL}^{-1} \mathrm{~h}^{-1}$ ), (b) rates of excretion of organic carbon (EOC, in $\mu \mathrm{g} \mathrm{CL}^{-1} \mathrm{~h}^{-1}$ ), (c) heterotrophic bacterial production ( $\mathrm{HBP}$, in $\left.\mu \mathrm{g} \mathrm{CL}^{-1} \mathrm{~h}^{-1}\right)$, (d) bacterial respiration (BR, in $\mu \mathrm{g} \mathrm{CL}^{-1} \mathrm{~h}^{-1}$ ), (e) bacterial growth efficiency (BGE), and (f) ratio of bacterial carbon demand to excretion of organic carbon (BCD : EOC) as a percentage. The horizontal line in (f) represents a balanced commensalistic phytoplankton-bacteria relationship. The vertical error lines on top of the bars are the standard deviation, whereas the letters indicate differences among treatments.

significant differences of BGE (Fig. 2e). There was, nevertheless, a significant UVR $\times$ STRAT interaction on BGE
(Table 3). No relationship was found between EOC rate and BGE $\left(R^{2}=0.149 p>0.05\right)$. Finally, to quantify the capacity of $\mathrm{C}$ released by phytoplankton to support the bacterial $\mathrm{C}$ demand $(\mathrm{BCD})$ in each treatment, the $\mathrm{BCD}$ : $\mathrm{EOC}$ ratio (as a percentage) was calculated (Fig. 2f). Carbon released by phytoplankton resulted in excess to meet $\mathrm{BCD}$ (i.e., $\mathrm{BCD}$ : EOC values $<100 \%$ ) only in the PAB-subsurface treatment (Fig. 2f).

\subsection{Joint effects of UVR and stratification on phytoplanktonic and bacterial metabolism in the low-UVR lake}

UVR exerted negative effects on both epilimnetic (Fig. 3) and hypolimnetic (Fig. 4) communities. For the epilimnetic community, PP was significantly lower in the PAB than in PA and $P$ treatments under subsurface conditions, while UVR did not affect PP under mixed conditions (Fig. 3a). A significant UVR $\times$ STRAT effect on PP (Table 3) was found, with the lowest PP values for the PAB-subsurface treatment. The highest values of UV-B (37\%) and UV-A (25\%) inhibition were found at the subsurface (Table 4). As for PP, EOC was significantly lower in the PAB than in the PA and $\mathrm{P}$ treatments at the subsurface, but non-significant differences among radiation treatments under mixed conditions were found (Fig. 3b). \%EOC did not show differences among radiation treatments in both stratification conditions (graph (2) in Appendix A). HBP showed significantly higher values in dark treatments at the subsurface than under mixed conditions (Fig. 3c), generating a significant interactive effect of UVR $\times$ STRAT on HBP (Table 3 ). Noticeably, a strong inhibition of HBP by UV-B and UV-A in subsurface and in mixed conditions was found (Table 4). By contrast, the estimated BR was not significantly affected by any factor (Table 3 ; Fig. $3 d$ shows $\mathrm{BR}_{50 \%}$ ). UVR was the only factor that significantly reduced BGE values in both mixed and subsurface conditions (Fig. 3e). No relationship between EOC rate and BGE was found $\left(R^{2}=0.055 p>0.05\right)$. The BCD : $\mathrm{EOC}(\%)$ 
Epilimnetic community low̄-UVR lake
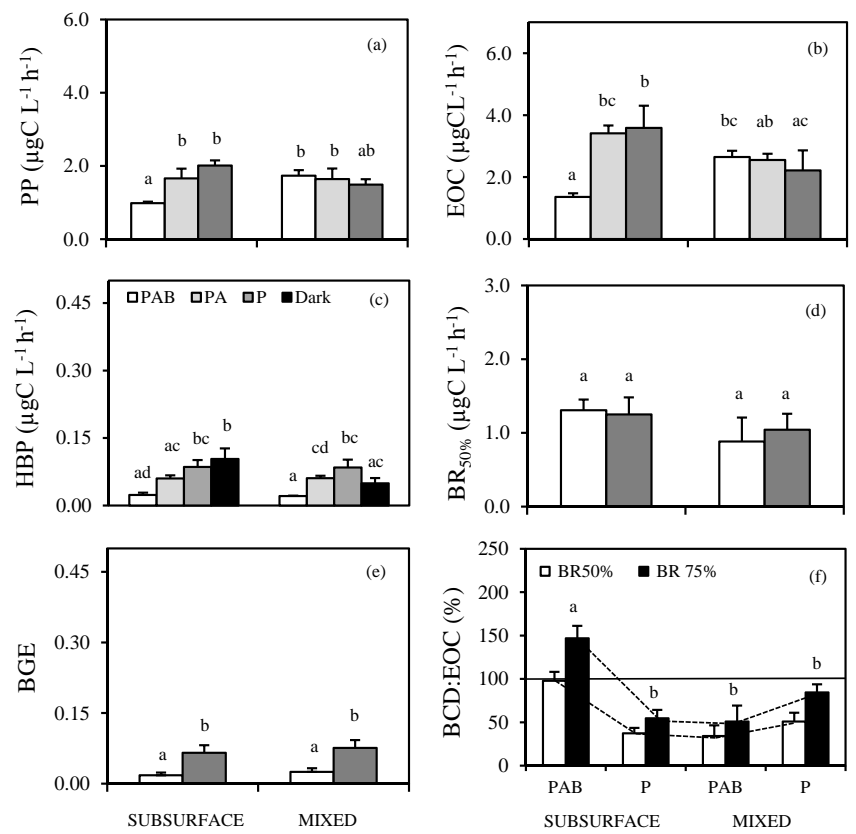

Figure 3. Metabolic variables of epilimnetic community under different radiation treatments (PAB, PA, $\mathrm{P}$, dark) and different stratification conditions (subsurface, mixed) in the low-UVR lake. (a) Primary production ( $\mathrm{PP}$, in $\mu \mathrm{g} \mathrm{CL}^{-1} \mathrm{~h}^{-1}$ ); (b) rate of excretion of organic carbon (EOC, in $\mu \mathrm{g} \mathrm{CL}^{-1} \mathrm{~h}^{-1}$ ); (c) heterotrophic bacterial production (HBP, in $\mu \mathrm{g} \mathrm{CL^{-1 }} \mathrm{h}^{-1}$ ); (d) bacterial respiration $\left(\mathrm{BR}_{50 \%}\right.$ in $\left.\mu \mathrm{g} \mathrm{CL}^{-1} \mathrm{~h}^{-1}\right)$, calculated as $50 \%$ of total planktonic respiration (TPR); (e) bacterial growth efficiency (BGE); and (f) ratio of bacterial carbon demand to excretion of organic carbon (BCD: EOC) as a percentage. The broken lines indicate the minmax range of the $\mathrm{BCD}: \mathrm{EOC}(\%)$ ratio, with $\mathrm{BCD}$ calculated assuming BR as either 50 or $75 \%$ of TPR. The horizontal line in (f) represents a balanced commensalistic phytoplankton-bacteria relationship. The vertical error lines on top of the bars are the standard deviation, whereas the letters indicate differences among treatments.

was $<100 \%$ for every experimental condition except for that under PAB-subsurface treatment, where the BCD: $\mathrm{EOC} \mathrm{( \% )}$ reached values from $\sim 100 \%$ (assuming $B R=50 \%$ of TPR) to $145 \%$ (assuming BR $=75 \%$ of TPR) (Fig. 3f). Thus, in this latter case (PAB-subsurface), EOC was not enough to meet BCD.

For the hypolimnetic community, UVR was the only factor that significantly inhibited PP (Fig. 4a). Samples under the PAB and PA treatments had significantly lower PP values than those under the $\mathrm{P}$ treatment in both subsurface and mixed conditions (Fig. 4a). The EOC rates were significantly lower in the PAB and PA treatments than in the P treatment at the subsurface (Fig.4b). No significant differences among both stratification treatments were determined when comparing each radiation treatment (Fig. 4b). HBP was only significantly inhibited by UV-B (Fig. 4c), whereas it was stimu-
Hypolimnetic community low-UVR lake
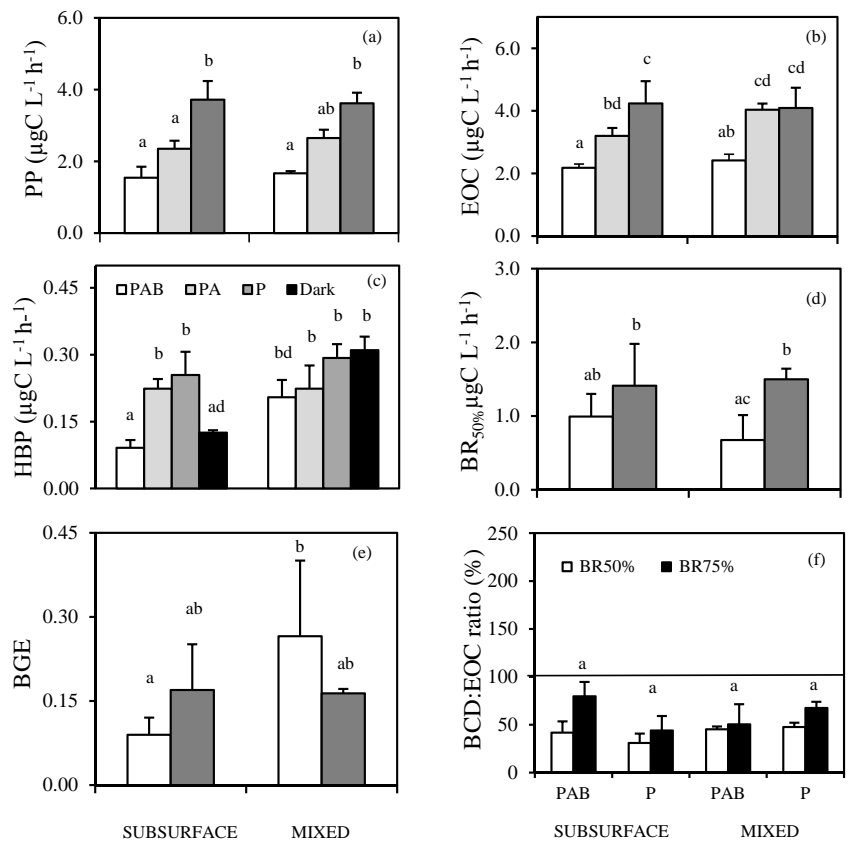

Figure 4. Metabolic variables of hypolimnetic community under different radiation treatments (PAB, PA, P, dark) and different stratification conditions (subsurface, mixed) in the low-UVR lake. (a) Primary production (PP, in $\mu \mathrm{g} \mathrm{C} \mathrm{L}^{-1} \mathrm{~h}^{-1}$ ); (b) rates of excretion of organic carbon (EOC, in $\mu \mathrm{C} \mathrm{CL}^{-1} \mathrm{~h}^{-1}$ ); (c) heterotrophic bacterial production (HBP, in $\left.\mu \mathrm{g} \mathrm{CL}^{-1} \mathrm{~h}^{-1}\right)$; (d) bacterial respiration $\left(\mathrm{BR}_{50 \%}\right.$ in $\mu \mathrm{g} \mathrm{CL}^{-1} \mathrm{~h}^{-1}$ ), calculated as $50 \%$ of total planktonic respiration (TPR); (e) bacterial growth efficiency (BGE); and (f) ratio of bacterial carbon demand to excretion of organic carbon (BCD : EOC) as percentage, calculated assuming BR as either 50 or $75 \%$ of TPR. The horizontal line in (f) represents a balanced commensalistic phytoplankton-bacteria relationship. The vertical error lines on top of the bars are the standard deviation, whereas the letters indicate differences among treatments.

lated by PA and P under subsurface conditions (Fig. 4c). Under mixing, however, UVR did not affect HBP. Therefore, subsurface exposure triggered the inhibition due to UV-B by $45.6 \%$ (Table 4 ). Only UVR, as a single factor, significantly affected BR (Table 3), with the lowest values under the PAB-mixed treatment (Fig. 4d), whereas only the STRAT factor affected BGE, with the lowest BGE values in the PAB-subsurface treatment (Fig. 4e). The BCD : $\operatorname{EOC}(\%)$ was $<100 \%$ under all conditions (assuming BR $=50$ or $75 \%$ of TPR), indicating the EOC was always capable of supporting BCD (Fig. 4f).

To summarize, and taking into account the changes $(\Delta)$ in the inhibitory UVR effect (UV-B and UV-A) on PP and HBP with increased stratification (Table 4), our results reveal greater UV-B sensitivity of (i) epilimnetic phytoplankton and heterotrophic bacteria communities in the low-UVR lake than in the high-UVR lake, (ii) epilimnetic phytoplankton 
than heterotrophic bacteria in both lakes, and (iii) hypolimnetic heterotrophic bacterial than phytoplankton community in the low-UVR lake. In addition, significant interactive UVR $\times$ STRAT effects were observed on the BCD : EOC $(\%)$ only in the epilimnetic communities (Table 3). Thus, partially supporting our hypothesis, the BCD : EOC (\%) significantly decreased under PAB-subsurface treatment in the high-UVR lake but increased in the low-UVR lake.

\section{Discussion}

The main outcome of our work is that the increased stratification of the water column altered the commensalistic phytoplankton-bacteria relationship in oligotrophic lakes. The present study is the first so far to directly assess the interactive effects of UVR and stratification changes on phytoplankton and bacteria and their commensalistic relationship in freshwater ecosystems. Furthermore, in our complex experimental approach, we simulated reductions in the depth of the UML due to the stratification of the water column (one of the potential consequences of global warming; Gao et al., 2012; de Senerpont-Domis et al., 2013). Under these conditions, we measured the extracellular carbon release by phytoplankton and directly determined the BR, as these are the key variables implied in the ratio of bacterial carbon demand to $\mathrm{C}$ supply. Moreover, since a strong feedback between physical processes (e.g., mixing, stratification) and changes in DOC concentration in small lakes has previously been reported (Read and Rose, 2013), we further achieved an advance in our knowledge by investigating two oligotrophic ecosystems that differed in their UVR penetration in the water column due to their DOC content, selected as model lakes representing two ends of an optical gradient of transparence to UVR in Mediterranean inland waters. This provides a framework for disentangling the complex processes that underlie biological interactions under changing physical (stratification, UVR) and chemical (DOC) conditions, which can then modify the $\mathrm{C}$ flux in aquatic ecosystems.

\subsection{Sensitivity of phytoplankton and bacteria to UVR and stratification}

Despite the physical and ecological differences between the two lakes, PP and HBP responses to the joint effect of UVR and stratification were quite similar in that the latter augmented the effect size of UV-B, mainly on the epilimnetic communities in both ecosystems. This effect reached a higher magnitude in the low-UVR lake (Table 4), which coincided with a greater relative exposure to UV-B (9-fold) and an more accentuated decrease in the UV-A : UV-B ratio (58\%) at the shallower layer in the low-UVR than in the high-UVR lake. This result agrees with the findings of higher UVR damage to primary producers in low-UVR lakes than in high-UVR lakes as reported by Helbling et al. (2013), although in their study

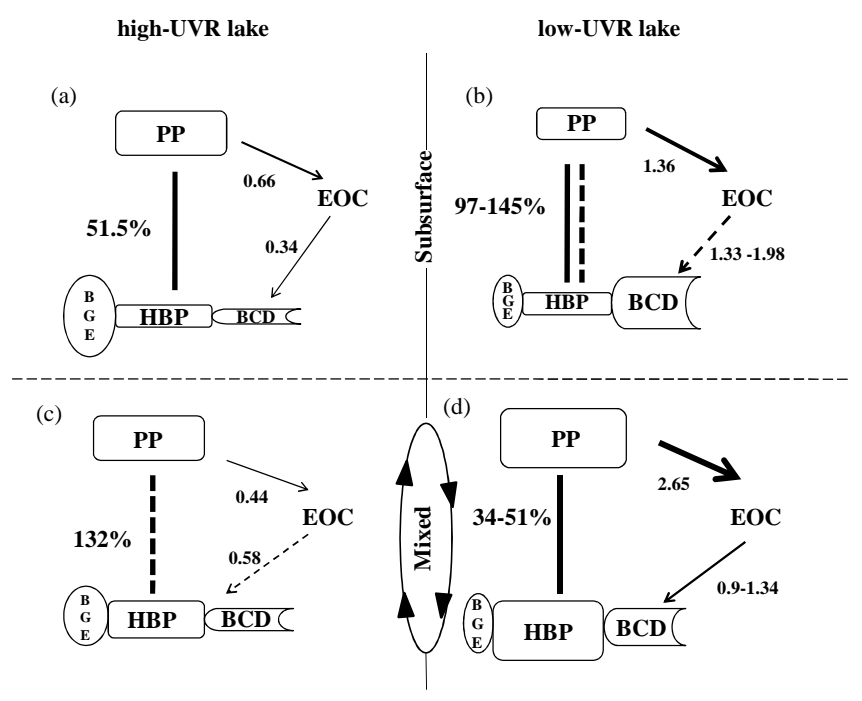

Figure 5. Epilimnetic phytoplankton-bacteria relationship under PAB-subsurface and PAB-mixed conditions in the high-UVR lake (a, c) and low-UVR lake (b, d). The sizes of the boxes are proportional to the magnitude of the rates (in $\mu \mathrm{C} \mathrm{L}^{-1} \mathrm{~h}^{-1}$ ). The absolute numbers are values of excretion of organic carbon (EOC) rates and bacterial carbon demand (BCD), and the percentage numbers are values of the $\mathrm{BCD}: \mathrm{EOC}(\%)$ ratio. The thicknesses of the arrows indicate the relative magnitude of a particular carbon flux. The broken-line arrows indicate that EOC is not enough to satisfy BCD. Thick black lines represent the BCD:EOC $(\%)$ ratio, indicating either coupled (solid lines) or uncoupled (broken lines) phytoplankton-bacteria relationship. PP: primary production; HBP: heterotrophic bacterial production; BGE: bacterial growth efficiency. Numbers are rates of C flux (in $\mu \mathrm{g} \mathrm{CL}^{-1} \mathrm{~h}^{-1}$ ).

this response was found only under fluctuating irradiances. The results presented here indicate increased susceptibility to UVR of bacteria and phytoplankton communities relatively less exposed to UV-B during their life cycles (Pakulski et al., 2007; Harrison and Smith, 2011a). Interestingly, the UVR effect on \%EOC was only significant in the highUVR lake; the release of $\mathrm{C}$ has been described as a protective mechanism to prevent photosystem damage from reducing power excess under high irradiance of PAR (Wood and Van Valen, 1990) as well as UVR (Carrillo et al., 2002, 2008). The lack of this "escape valve", which helps to prevent overexcitation of PSII, might be the final cause of the higher sensitivity of phytoplankton communities in the low-UVR lakes. In addition, a higher sensitivity to UVR was found for epilimnetic phytoplankton than for bacteria mainly under subsurface conditions, suggesting that photosynthetic processes are more sensitive under extreme conditions that mimic the global-warming scenario. This result contrasts with previous reports of greater UVR damage to bacterioplankton than to phytoplankton in oligotrophic waters of the Mediterranean Sea (Bertoni et al., 2011), the northern South China Sea (Yuan et al., 2011), high-mountain lakes (Sommaruga et al., 1997), and boreal lakes (Xenopoulos and Schindler, 2003). 
Taken all together, our results show that increased stratification, by trapping the cells in a shallower epilimnion, with increased UVR exposure triggered or exacerbated the inhibitory effect of UVR on phytoplanktonic and bacterial metabolism measured under mixed conditions. Because this negative effect was greater in high-DOC waters, we propose that the "ideal" photoprotective DOM may become harmful on planktonic communities in a scenario of increased stratification. Our proposal is based on the indirect harmful UV-B effects due to the free radicals $\left(\mathrm{O}_{2}^{-}, \mathrm{H}_{2} \mathrm{O}_{2}, \mathrm{OH}^{-}\right)$generated by photooxidation of the DOC (Banaszak, 2003; Pullin et al., 2004), which can exacerbate the negative UVR effect in lowUVR lakes. In addition, DOC would become bleached and therefore the lake would be more UVR transparent (Reche et al., 2001), thus increasing the negative effect of UVR on organisms. However, cell acclimation to UVR or a shift in the taxonomic composition towards UVR-resistant species could counteract the net negative UVR effect on a long-term scale.

As expected, UVR was the main factor that affected the non-acclimated hypolimnetic community, since PP and HBP underwent negative UV-B and UV-A effects in both subsurface and mixed conditions (Table 4). These responses reflect the higher sensitivity of the hypolimnetic than the epilimnetic community to UVR, because only the hypolimnetic community was negatively affected by UVR under mixed conditions. These results agree with previous reports of higher photosynthetic impairment under UVR exposure of phytoplankton from deep chlorophyll maxima (Harrison and Smith, 2011b) or from the bottom of the mixed layer (Xenopoulos and Schindler, 2003).

Nevertheless, HBP of the hypolimnetic community was stimulated by UV-A and PAR when exposed to shallower conditions. These results suggest that the hypolimnetic bacteria possessed photorepair mechanisms, via UV-A and PARpromoted photolyase activity (DNA repair), which may be activated after $4 \mathrm{~h}$ of UVR and PAR exposure (Jeffrey et al., 1996; Bertoni et al., 2012). This photorepair mechanism has a low energy cost and may be an important adaptive mechanism to attenuate the gross negative effect of UVR when a non-UVR-acclimated bacterioplankton community is exposed to high PAR and UV-A intensity and harmful UV-B levels in ecosystems with low nutrient availability (MedinaSánchez et al., 2002). Nevertheless, and in agreement with our hypothesis, photorepair mechanisms were insufficient to completely counteract UVR-induced damage, this being concordant with a sharp decrease in the UV-A : UV-B ratio $(58 \%)$ in the upper layers (subsurface conditions). Moreover, the increased HBP found after exposure of samples to higher PAR intensity in the upper layers is consistent with the previously reported stimulatory effect of PAR on HBP (Morán et al., 2001; Medina-Sánchez et al., 2002; Pakulski et al., 2007). Furthermore, a potential presence of aerobic anoxygenic phototrophic bacteria (Bertoni et al., 2011; Mašín et al., 2012; Ferrara et al., 2011) should not be ruled out in account- ing for the increased HBP under high PAR in the low-UVR lake.

\subsection{UVR and increased stratification effect on the commensalistic phytoplankton-bacteria relationship}

As noted above, UVR and stratification exerted an interactive effect on PP and HBP in the epilimnetic layer in both lakes. However, this interactive effect was only exerted on EOC in the low-UVR lake, where the EOC rates values were 3-fold higher (except under PAB-subsurface treatment) than in the high-UVR lake. The carbon released by phytoplankton is composed mainly of low-molecular-weight compounds that are readily assimilable by bacteria (Amon et al., 2001). This source of carbon is preferred by bacteria, even in lakes with considerable input of terrestrial carbon to subsidize their growth (Kritzberg et al., 2005, 2006), because the non-readily assimilable organic matter, mostly composed of high-molecular-weight compounds, must be hydrolyzed by bacterial ectoenzymes before the assimilation.

Quantification of the dependence of heterotrophic bacteria on organic substrate released by phytoplankton requires an accurate assessment of the BCD (Morán et al., 2002). Our study offers a quite precise estimate of the BCD, because both HBP and BR were directly measured in the high-UVR lake, due to the absence of size overlap between auto- and heterotrophic organisms. In the low-UVR lake, where segregation between both biological fractions was not feasible, BR was estimated from direct measurements of TPR and the reported percentages of the latter variable accounted for BR (i.e., 50 and $75 \%$; Lemeé et al., 2002; Robinson, 2008). This procedure brought about a min-max range where the actual BR should safely fall. In addition, its reliability is supported in that our estimated mean BGE and BR values fell within the range reported for oligotrophic ecosystems (Biddanda et al., 2001; Amado et al., 2013).

In the high-UVR lake, BGE was increased under full-sunlight and subsurface conditions, reflecting greater changes in bacterial respiration than in production. The reduction in BR and, as a consequence, the increase in bacterial growth efficiency could be interpreted as a tolerance-related mechanism under full-sunlight exposure in accordance with the non-inhibitory effect of UV-B on HBP found under shallower conditions. By contrast, in the low-UVR lake, BGE values were lower under full-sunlight and subsurface (stratified) conditions. The lack of the inhibitory effect of fullsunlight (PAB vs. P) on TPR (and hence BR) concomitantly with a strong inhibitory effect of UV-B on HBP determined a reduction in bacterial growth efficiency according to the high sensitivity of the bacterial community. The differences in the bacterial responses between the lakes could be the outcome of specific bacterial composition inhabiting each lake. These results agree with previous laboratory findings of a negative UV-B effect on BGE or BR in some bacterial strains isolated 
from alpine lakes, but a positive effect on others, suggesting a strain-specific response (Hörtnagl et al., 2010). Nevertheless, changes in BGE are frequently observed when bacterial growth is limited by substrate availability (del Giorgio and Cole, 1998; López-Urrutia and Morán, 2007). Although our experiments were not specifically designed to test the role of organic substrates on BGE, we did not find a significant direct relationship between EOC rate and BGE in each lake. Thus, our data support the view that BGE can be altered by direct solar UVR impact.

Regarding the commensalistic phytoplankton-bacteria relationship, it was noticeable that EOC rates in the high-UVR ecosystem increased with full-sunlight under subsurface conditions, reaching values that exceeded the $\mathrm{C}$ demand of a bacterial community which seemed to have undergone an inactivation or dormancy under PAB, reflected by lower respiration. This slowing of the bacterial metabolism, concomitant with an increase in the availability of $\mathrm{C}$ released by phytoplankton, was the mechanism that determined the "coupling" phytoplankton-bacteria relationship. However, the fate of the $\mathrm{C}$ released by phytoplankton could be a transitory accumulation in lake water until its consumption by enhanced bacterial metabolic processes (growth and respiration) after an improvement in the light conditions, or could be definitively incorporated into the dissolved-C pool of the lake water.

In the low-UVR ecosystem, particularly the epilimnetic community, the strong inhibitory effect of UV-B at the subsurface on PP (i.e., decreasing $\mathrm{C}$ incorporation) was also reflected in a lesser $\mathrm{C}$ release by phytoplankton under these conditions. These decreased EOC rates did imply a change in their capability to meet the BCD, which ranged from barely sufficiency (if a $50 \%$ loss of TPR is assumed) to nonsufficiency (if a $75 \%$ loss of TPR is assumed). Therefore, the estimated min-max interval for each experimental condition shows an unexpected trend to a weakening of the bacterial dependence on phytoplankton $\mathrm{C}$ under full-sunlight and subsurface conditions in the low-UVR lake, which may be induced by global warming. These results partially support our hypothesis because the interaction between UVR and stratification strengthened the commensalistic phytoplanktonbacteria relationship (decreasing the $\mathrm{BCD}$ : $\mathrm{EOC}(\%)$ ratio to $<100$ ) in the high-UVR lake, but weakened (increasing the $\mathrm{BCD}: \mathrm{EOC}(\%)$ ratio to $>100)$ this relationship in the lowUVR lake (Figs. 2f and 3f). Moreover, they underline the capability of UVR in altering the efficiency of phytoplankton $\mathrm{C}$ excretion to support bacterial demands in optically contrasting ecosystems. Since the interaction of UVR and simulated stratification on this crucial biotic interaction in high-UVR and low-UVR lakes has not been previously examined, more data are needed in order to generalize these responses by microbial organisms, not only on a short-term (as considered in this study) but also a long-term basis.
To summarize our findings, we propose a conceptual functioning model that embraces both contrasting model ecosystems (Fig. 5). According to the global-warming scenario, it is expected that (i) the vertical stratification of aquatic ecosystems will intensify (de Senerpont Domis et al., 2013), (ii) the depth of the mixed layer will be altered as a consequence of micro-stratification in shallow lakes (van de Waal et al., 2009), and (iii) microbial communities and DOC will be confined within a highly irradiated layer. Based on our results, the synergistic effect of UVR and increased stratification on the microbiota might strengthen the $\mathrm{C}$ flux through the microbial loop in the high-UVR lake (or increasing the DOC pool in the lake) but might weaken it in the low-UVR lake. Therefore, our results showing greater UVR damage in the low-UVR lake imply that these types of ecosystems might be especially vulnerable to these factors related to global change. 


\section{Appendix A}

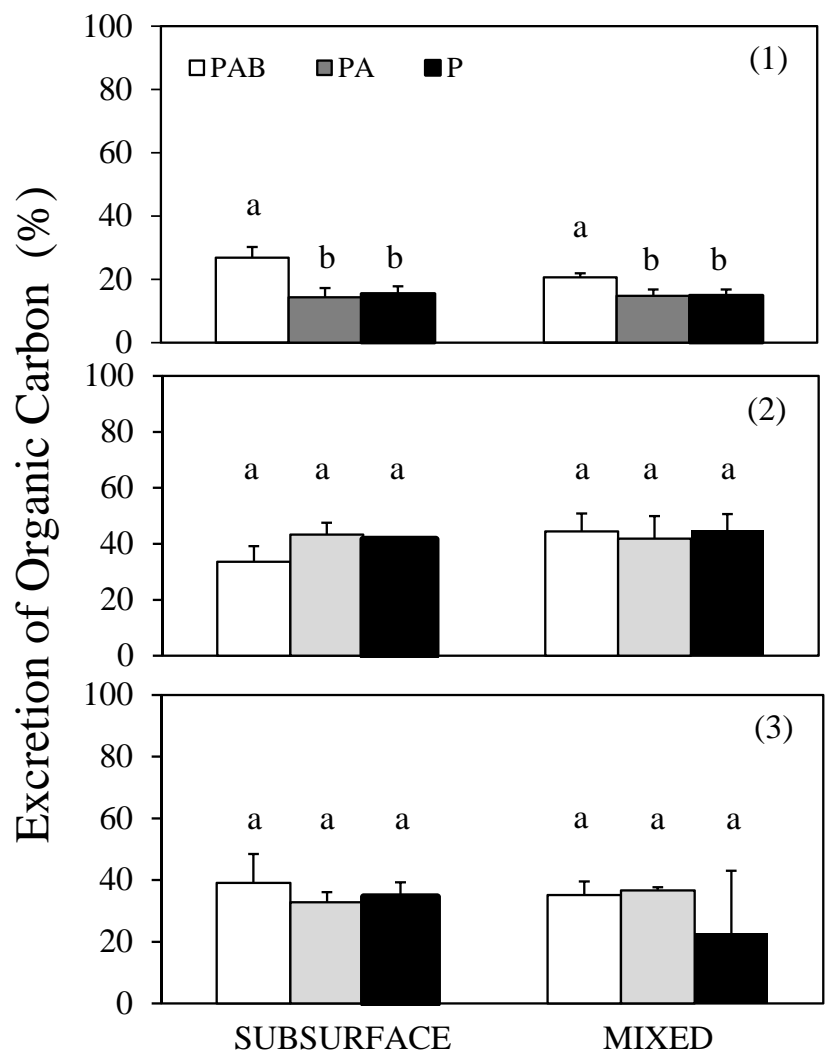

Figure A1. Percentage of excretion of organic carbon rates (\%EOC) under different radiation (PAB, PA, P) and stratification conditions (subsurface, mixed) in (1) an epilimnetic community in the high-UVR lake, (2) an epilimnetic community in the low-UVR lake, and (3) a hypolimnetic community in the low-UVR lake. The vertical error lines on top of the bars are the standard deviation, whereas the letters indicate differences among treatments. 
Author contributions. P. Carrillo, E. W. Helbling, and V. E. Villafañe conceived and designed the experiments. P. Carrillo, J. M. Medina-Sánchez, C. Durán, G. Herrera, E. W. Helbling, and V. E. Villafañe performed the experiments. P. Carrillo, J. M. Medina-Sánchez, and E. W. Helbling analyzed the data. P. Carrillo contributed reagents/materials/analysis tools. P. Carrillo, J. M. Medina-Sánchez, E. W. Helbling, and V. E. Villafañe wrote the paper.

Acknowledgements. This study was supported by the Ministerio Español de Medio Ambiente, Rural y Marino (PN2009/067), Ciencia e Innovación (CGL2011-23681), Junta de Andalucía (Excelencia CVI-02598 and P09-RNM-5376), Consejo Nacional de Investigaciones Científicas y Técnicas - CONICET (PIP no. 112-201001-00228), and Fundación Playa Unión. G. Herrera and C. Durán were supported by a Formación de Profesorado Universitario grant from the Spanish government. The authors are indebted to the staff of Sierra Nevada National Park and Lagunas de Ruidera Natural Park for permission to work, to E. Jiménez-Coll for the bacterial production analysis, and to D. Nesbitt for writing assistance in English. We also thank the two anonymous reviewers for helping us to improve the quality of this manuscript. This is the contribution no. 152 of Estación de Fotobiología Playa Unión.

Edited by: G. Herndl

\section{References}

Aas, P., Lyons, M. M., Pledger, R., Mitchell, D. L., and Jeffrey, W. H.: Inhibition of bacterial activities by solar radiation in nearshore waters and the Gulf of Mexico, Aquat. Microb. Ecol., 11, 229-238, 1996.

Amado, A. M., Meirelles-Pereira, F., Vidal, L.O., Sarmento, H., Suhett, L., Farjalla, V. F, Cotner, J. B., and Roland, F.: Tropical freshwater ecosystems have lower bacterial growth efficiency than temperate ones, Front. Microbiol., 4, 1-8, 2013.

American Public Health Association (APHA): Standard methods for the examination of water and wastewater, 18th Edn. American Public Health Association, Washington DC, 1992.

Amon, R. M. W., Fitznar, H.-P., and Bennerm, R.: Linkages among the bioreactivity, chemical composition and diagenetic state of marine dissolved organic matter, Limnol. Oceanogr., 46, 287297, 2001.

Baines, S. B. and Pace, M. L.: The production of dissolved organicmatter by phytoplankton and its importance to bacteria- patterns across marine and fresh-water systems, Limnol. Oceanogr., 36, 1078-1090, 1991.

Banaszak, A. T.: Photoprotective physiological and biochemical responses of aquatic organisms, in: UV effects in aquatic organisms and ecosystems, edited by: Helbling, E. W. and Zagarese, H. E., Roy. Soc. Chem., Cambridge, UK, 329-356, 2003.

Barbieri, E. S., Villafañe, V. E., and Helbling, E. W.: Experimental assessment of UVR effects on temperate marine phytoplankton when exposed to variable radiation regimes, Limnol. Oceanogr., 47, 1648-1655, 2002.
Bell, R. T.: Estimating production of heterotrophic bacterioplankton via incorporation of tritiated thymidine, in: Handbook of methods in aquatic microbial ecology, edited by: Kemp B. F., Sherr E. B., and Cole J. J., Lewis Publishers, Boca Raton, FL, 495-503, 1993.

Bertoni, R., Jeffrey, W. H., Pujo-Pay, M., Oriol, L., Conan, P., and Joux, F.: Influence of water mixing on the inhibitory effect of UV radiation on primary and bacterial production in Mediterranean coastal water, Aquat. Sci., 73, 377-387, 2011.

Biddanda, B. A., Ogdahl, M., and Cotner, J. B.: Dominance of bacterial metabolism in oligotrophic relative to eutrophic waters, Limnol. Oceanogr., 46, 730-739, 2001.

Carrillo, P., Reche, I., Sánchez-Castillo, P., and Cruz-Pizarro, L.: Direct and indirect effects of grazing on the phytoplankton seasonal succession in an oligotrophic lake, J. Plankton Res., 17, 1363-1379, 1995.

Carrillo, P., Medina-Sánchez, J. M., and Villar-Argaiz, M.: The interaction of phytoplankton and bacteria in a high-mountain lake: Importance of the spectral composition of solar radiation, Limnol. Oceanogr., 47, 1294-1306, 2002.

Carrillo, P., Medina-Sánchez, J. M., Villar-Argaiz, M., DelgadoMolina. J. A., and Bullejos, F. J.: Complex interactions in microbial food webs: Stoichiometric and functional approaches, Limnética, 25, 189-204, 2006.

Carrillo, P., Delgado-Molina, J. A., Medina-Sánchez, J. M., Bullejos, F. J., and Villar-Argaiz, M.: Phosphorus inputs unmask negative effects of ultraviolet radiation on algae in a high-mountain lake, Global Change Biol., 14, 423-439, 2008.

Cole, J. J., Findlay, S., and Pace, M. L.: Bacterial production in fresh and saltwater ecosystems: a cross-system overview. Mar. Ecol. Prog. Ser., 43, 1-10, 1988.

del Giorgio, P. A. and Cole, J. J.: Bacterial growth efficiency in natural aquatic systems, Annu. Rev. Ecol. Syst., 29, 503-541, 1998.

de Senerpont Domis, L.N., Elser, J. J., Gsell, A. S., Huszar, V. L. M., Ibelings, B. W., Jeppesen, E., Kosten, S., Mooij, W. M., Roland, F., Sommer, U., Van Donk, E., Winder, M., and Lurling, M.: Plankton dynamics under different climatic conditions in space and time. Freshwater Biol., 58, 463-482, 2013.

Ferrara, I., Gasol, J. M., Sebastián, M., Hojerová, E., and Koblížek, M.: Comparison of growth rates of aerobic anoxygenic phototrophic bacteria and other bacterioplankton groups in coastal Mediterranean waters, Appl. Environ. Microb., 77, 7451-7458, 2011.

Fouilland, E. and Mostajir, B.: Revisited phytoplanktonic carbon dependency of heterotrophic bacteria in freshwaters, transitional, coastal and oceanic waters, FEMS Microbiol. Ecol., 73, 419429, 2010.

Fouilland, E. and Mostajir, B.: Complementary support for the new ecological concept of "bacterial independence on contemporary phytoplankton production" in oceanic waters, FEMS Microbiol. Ecol., 78, 206-209, 2011.

Gao, K., Wu, Y., Li, G., Wu, H., Villafañe, V. E., and Helbling, E. W.: Solar UV radiation drives $\mathrm{CO}_{2}$ fixation in marine phytoplankton: a double-edged sword, Plant Physiol., 44, 54-59, 2007.

Gao, K., Helbling, E. W., Häder, D. P., and Hutchins, D. A.: Responses of marine primary producers to interactions between ocean acidification, solar radiation, and warming Mar, Ecol. Prog. Ser., 470, 67-189, 2012. 
Gasol, J. M., Vázquez-Domínguez, E., Vaqué, D., Agustí, S., and Duarte, C. M.: Bacterial activity and diffusive nutrient supply in the oligotrophic Central Atlantic Ocean, Aquat. Microb. Ecol., $56,1-12,2009$.

Genty, B. E., Briantais, J. M., and Baker, N. R.: Relative quantum efficiencies of the two photosystems of leaves in photorespiratory and non-photorespiratory conditions, Plant Physiol. Biochem., 28,1-10,1989.

Häder, D. P., Helbling, E. W., Williamson, C. E., and Worrest, R. C.: Effects of UV radiation on aquatic ecosystems and interactions with climate change, Photochem. Photobiol. Sci., 10, 242-260, 2011.

Harrison J. W. and Smith, R. E. H.: Effects of ultraviolet radiation on the productivity and composition of freshwater phytoplankton communities, Photochem. Photobiol. Sci., 8, 1218-1232, 2009.

Harrison J. W. and Smith, R. E. H.: The spectral sensitivity of phytoplankton communities to ultraviolet radiation-induced photoinhibition differs among clear and humic temperate lakes, Limnol. Oceanogr., 56, 2115-2126, 2011a.

Harrison J. W. and Smith, R. E. H.: Deep chlorophyll maxima and UVR acclimation by epilimnetic phytoplankton, Freshwater Biol., 56, 980-992, 2011b.

Helbling, E. W., Villafañe, V. E., and Holm-Hansen, O.: Effects of ultraviolet radiation on Antarctic marine phytoplankton photosynthesis with particular attention to the influence of mixing, in: Ultraviolet Radiation in Antarctica: Measurements and Biological Effects, edited by: Weiler, S. and Penhale, P., American Geophysical Union, Washington, DC, USA, Antarctic Research Series, 62, 207-227, 1994.

Helbling, E. W., Marguet, E. R., Villafañe, V. E., and Holm-Hansen, O.: Bacterioplankton viability in Antarctic waters as affected by solar ultraviolet radiation, Mar. Ecol. Prog. Ser., 126, 293-298, 1995.

Helbling, E. W., Carrillo, P., Medina-Sánchez, J. M., Durán, C., Herrera, G., Villar-Argaiz, M., and Villafañe, V. E.: Interactive effects of vertical mixing, nutrients and ultraviolet radiation: in situ photosynthetic responses of phytoplankton from high mountain lakes in Southern Europe, Biogeosciences, 10, 1037-1050, doi:10.5194/bg-10-1037-2013, 2013.

Hörtnagl, P., Pérez, M. T., and Sommaruga, R.: Contrasting effects of ultraviolet radiation on the growth efficiency of freshwater bacteria, Aquat. Ecol., 45, 125-136, 2010.

Huisman, J., Pham, Thi, N., Karl, D. M., and Sommeijer, B.: Reduced mixing generates oscillations and chaos in the oceanic deep chlorophyll maximum, Nature, 439, 322-325, 2006.

IPCC: Climate Change 2013, Summary for Policymakers, edited by: Stocker, T. F., Qin, D., Plattner, G.-K., Tignor, M., Allen, S. K., Boschung, J., Nauels, A., Xla, Y., Bex, V., and Mldgley, P.: Cambridge University Press, Cambridge, UK and New York, NY, USA, 2013.

Jeffrey, W. H., Pledger, R. J., Aas, P., Hager, S., Coffin, R. B., VonHaven, R., and Mitchell, D. L.: Diel and depth profiles of DNA photodamage in bacterioplankton exposed to ambient solar ultraviolet radiation, Mar. Ecol.-Prog. Ser., 137, 283-291, 1996.

Kitidis, V., Tilstone, G. H., Serret, P., Smyth, T. J. Torres, R., and Robinson, C.: Oxygen photolysis in the Mauritanian upwelling: Implications for net community production, Limnol. Oceanogr., 59, 299-310, 2014.
Korbee, N., Carrillo, P., Mata, M. T., Rosillo, S., Medina-Sanchéz, J. M., and Figueroa, F. L.: Effects of ultraviolet radiation and nutrients on the structure-function of phytoplankton in a highmountain lake, Photochem. Photobiol. Sci., 11, 1087-1098, 2012.

Kritzberg, E. S., Cole, J. J., Pace, M. M, and Granéli, W.: Does autochthonous primary production drive variability in bacterial metabolism and growth efficiency in lakes dominated by terrestrial C inputs?, Aquat. Microb. Ecol., 38, 103-111, 2005.

Kritzberg, E. S., Cole, J. J., Pace, M. M, and Granéli, W.: Bacterial growth on allochthonous carbon in humic and nutrient enriched lakes: results from whole-lake ${ }^{13} \mathrm{C}$ addition experiments, Ecosystems, 9, 489-499, 2006.

Lee, S. and Fuhrman, J. A.: Relationships between biovolume and biomass of naturally derived marine bacterioplankton, Appl. Environ. Microb., 53, 1298-1303, 1987.

Lemeé, R., Rochelle-Newall, E., Van Wambeke, F., Pizay, M. D., Rinaldi, P., and Gattuso, J. P.: Seasonal variation of bacterial production, respiration and growth efficiency in the open NW Mediterranean Sea, Aquat. Microb. Ecol. , 29, 227-237, 2002.

López-Sandoval, D. C., Fernández, A., and Marañón, E.: Dissolved and particulate primary production along a longitudinal gradient in the Mediterranean Sea, Biogeosciences, 8, 815-825, doi:10.5194/bg-8-815-2011, 2011.

López-Urrutia, A. and Morán, X. A. G.: Resource limitation of bacterial production distorts the temperature dependence of oceanic carbon cycling, Ecology, 88, 817-822, 2007.

Mašín, M., Čuperová, Z., Hojerová, E., Salka, I., Grossart, H. P., and Koblížek, M.: Distribution of aerobic anoxygenic phototrophic bacteria in glacial lakes of northern Europe, Aquat. Microb. Ecol., 66, 77-86, 2012.

Medina-Sánchez, J. M., Villar-Argaiz. M., Sánchez-Castillo, P., Cruz-Pizarro, L., and Carrillo P.: Structure changes in a planktonic food web: biotic and abiotic controls, J. Limnol., 58, 213222, 1999.

Medina-Sánchez, J. M., Villar-Argaiz, M., and Carrillo, P.: Modulation of the bacterial response to spectral solar radiation by algae and limiting nutrients, Freshwater Biol., 47, 2191-2204, 2002.

Medina-Sánchez, J. M., Carrillo, P., Delgado-Molina, J. A., Bullejos, F. J., and Villar-Argaiz, M.: Patterns of resource limitation of bacteria along a trophic gradient in Mediterranean inland waters, FEMS Microbiol. Ecol., 74, 554-565, 2010.

Medina-Sánchez, J. M., Delgado-Molina, J. A., Bratbak, G., Bullejos, F. J., Villar-Argaiz, M., and Carrillo, P.: Maximum in the middle: Nonlinear response of microbial plankton to ultraviolet radiation and phosphorus, PLoS One, 8, e60223, doi:10.1371/journal.pone.0060223, 2013.

Morán, X. A. G. and Alonso-Sáez, L.: Independence of bacteria on phytoplankton? Unsufficient support to Fouilland \& Mostajir's (2010) suggested new concept, FEMS Microbiol. Ecol., 78, 203205, 2011.

Morán, X. A. G., Massana, R., and Gasol, J. M.: Light conditions affect the measurement of oceanic bacterial production via leucine uptake, Appl. Environ. Microb., 67, 3795-3801, 2001.

Morán, X. A. G., Estrada, M., Gasol, J. M., and Pedrós-Alio, C.: Dissolved primary production and the strength of phytoplankton bacterioplankton coupling in contrasting marine regions, Microb. Ecol., 44, 217-223, 2002. 
Neale, P. J., Helbling, E. W., and Zagarese, H. E.: Modulation of UVR exposure and effects by vertical mixing and advection, in: UV effects in aquatic organisms and ecosystems, edited by: Helbling, E. W. and Zagarese, H. E., Royal Society of Chemistry, Cambridge, UK, 108-134, 2003.

Norrman, B., Zweifel, U. L., Opkinson Jr., C. S., and Fry, B.: Production and utilization of dissolved organic carbon during an experimental diatom bloom, Limnol. Oceanogr., 40, 898-907, 1995.

Pakulski, J. D., Baldwin, A., Dean, A., Durkin, S., Karentz, D., Kelley, C. A., Scott, K., Spero, H. J., Wilhelm, S., and Jeffrey, W. H..: Responses of heterotrophic bacteria to latitudinal variation in solar irradiance, Aquat. Microb. Ecol., 47, 153-162, 2007.

Pérez, M. T. and Sommaruga, R.: Interactive effects of solar radiation and dissolved organic matter on bacterial activity and community structure, Environ. Microbiol., 9, 2200-2210, 2007.

Porter, K. G. and Feig, Y. S.: The use of DAPI for identifying and counting aquatic microflora, Limnol. Oceanogr., 25, 943-948, 1980.

Pullin, M. J., Bertilsson, S., Goldstone, J. V., and Voelker, B. M.: Effects of sunlight and hydroxyl radical on dissolved organic matter: Bacterial growth efficiency and production of carboxylic acids and other substrates, Limnol. Oceanogr., 49, 2011-2022, 2004.

Read, J. S. and Rose, K. C.: Physical responses of small temperate lakes to variation in dissolved organic carbon concentrations, Limnol. Oceanogr., 58, 921-931, 2013.

Reche, I., Pulido-Villena, E., Conde-Porcuna, J. M., and Carrillo, P.: Photoreactivity of dissolved organic matter from high mountain lakes of Sierra Nevada (Spain), Arct. Antarc. and Alpine Res., 33, 426-434, 2001

Robinson, C.: Hetrotrophic bacterial respiration, in: Microbial ecology of the oceans, 2nd Edn., edited by: Kirchman, D., Wiley, New York, 299-334, 2008.

Rocha, O. and Duncan, A.: The relationship between cell carbon and cell volume in freshwater algal species used in zooplankton studies, J. Plankton Res., 7, 279-294, 1985.

Rojo, C., Herrera, G., Rodrigo, M. A., Lorente, M. J., and Carrillo, P.: Mixotrophic phytoplankton is enhanced by UV radiation in a low altitude, P-limited Mediterranean lake, Hydrobiologia, 698, 97-110, 2012.
Rose, K. C., Williamson, C. E., Saros, J. E., Sommaruga, R., and Fischer, J. M.: Differences in UV transparency and thermal structure between alpine and subalpine lakes: implications for organisms, Photochem, Photobiol. Sci., 8, 1244-1256, 2009.

Ruiz-González, C., Simo, R., Sommaruga, R., and Gasol, J. M.: Away from darkness: a review on the effects of solar radiation on heterotrophic bacterioplankton activity, Front. Microbiol., 4, 131-131, 2013.

Sommaruga, R., Sattler, B., Oberleiter,A., Wille, A., SommarugaWögrath, S., Psenner, R., Felip, M., Camarero, L., Pina, S., Gironés, R., and Catalán, J.: An in situ enclosure experiment to test the solar UV-B impact on microplankton in a high altitude mountain lake: II. Effects on the microbial food web, J. Plankton Res., 21, 859-876, 1999.

van de Waal, D. B., Verschoor, A., Verspagen, J. M. H., Van Donk, E., and Huisman, J.: Climate-driven changes in the ecological stoichiometry of aquatic ecosystems, Front. Ecol. Environ. Sci., 8, 145-152, 2009.

Villafañe, V. E., Sundbäck, K., Figueroa, F. L., and Helbling, E. W.: Photosynthesis in the aquatic environment as affected by UVR, in: UV effects in aquatic organisms and ecosystems, edited by: Helbling, E. W. and Zagarese, H. E., Roy. Soc. Chem., 357-397, 2003.

Villafañe, V. E., Gao, K., Li, P., Li, G., and Helbling, E. W.: Vertical mixing within the epilimnion modulates UVR-induced photoinhibition in tropical freshwater phytoplankton from southern China, Freshwater Biol., 52, 1260-1270, 2007.

Warkentin, M., Freese, H. M., Karsten, U., and Schumann, R.: New and fast method to quantify respiration rates of bacterial and plankton communities in freshwater ecosystems by using optical oxygen sensor spots, Appl. Environ. Microb., 73, 6722-6729, 2007.

Williamson, C. E. and Rose, K. C.: When UV meets freshwater, Science, 329, 637-639, 2010.

Wood, A. M. and Van Valen L. M.: Paradox lost? On the release of energy-rich compounds by phytoplankton, Mar. Microb. Food Webs, 4, 103-116, 1990.

Xenopoulos, M. A. and Schindler, D. W.: Differential responses to UVR by bacterioplankton and phytoplankton from the surface and the base of the mixed layer, Freshwater Biol., 48, 108-122, 2003

Yuan, X., Yin, K., Harrison, P. J., and Zhang, J.: Phytoplankton are more tolerant to UV than bacteria and viruses in the northern South China Sea, Aquat. Microb. Ecol., 65, 117-128, 2011. 